Prepared in cooperation with the Bureau of Indian Affairs

\title{
Estimation of Volume and Mass and of Changes in Volume and Mass of Selected Chat Piles in the Picher Mining District, Ottawa County, Oklahoma, 2005-10
}
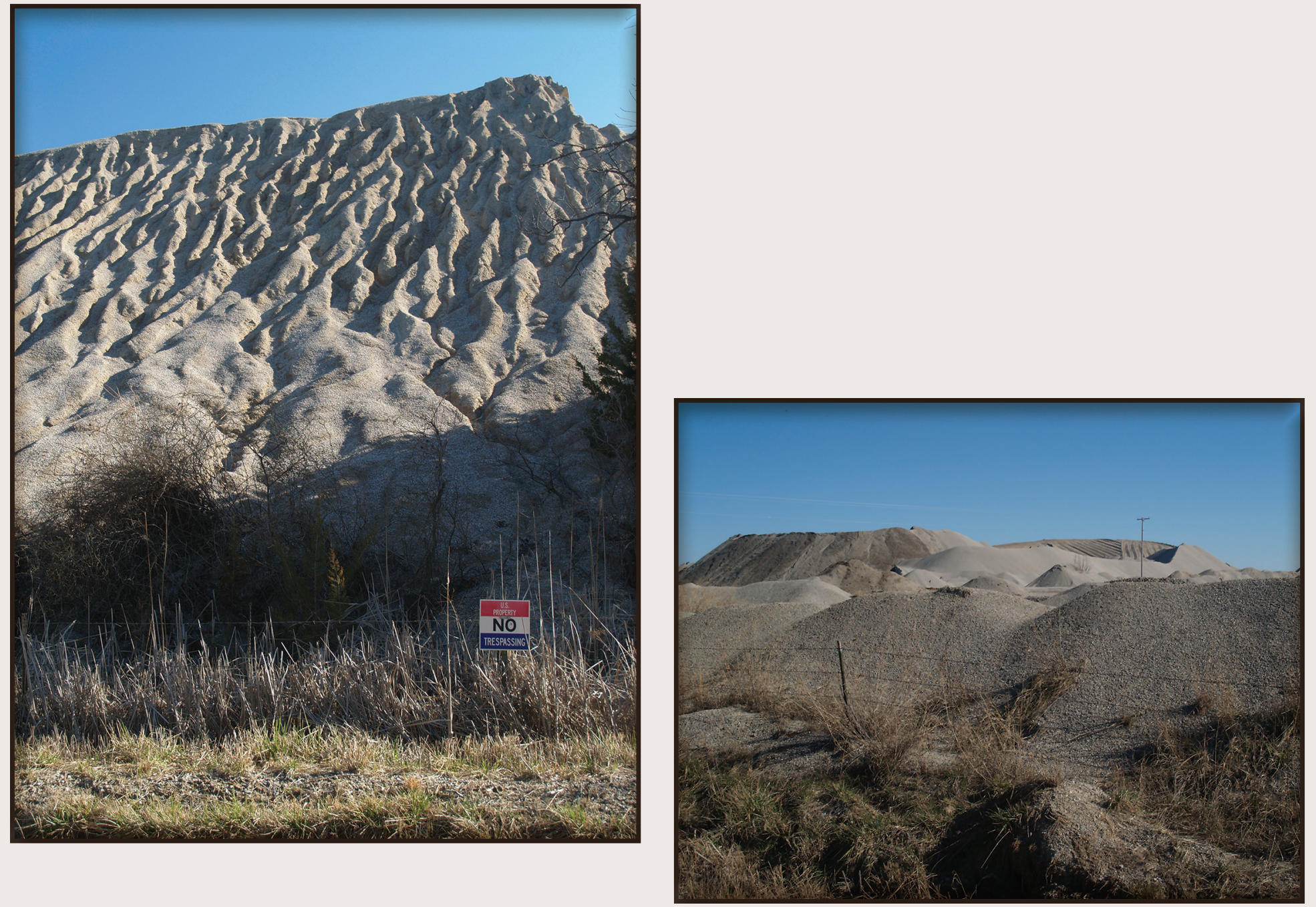

Scientific Investigations Report 2013-5011

U.S. Department of the Interior

U.S. Geological Survey 


\section{Front cover:}

Left, Eroded chat on the Sooner property.

Right, View of the Sooner chat pile oriented southeast, with small mounds of chat in the foreground.

Bottom banner, Panoramic view of a chat pile (CP039) on the St. Joe property, oriented east.

\section{Back cover:}

Top right, View from the north entrance to the Sooner property showing chat piles.

Bottom right, Closeup view of chat on the St. Joe property with a quarter dollar for scale.

Left, Small mound of chat beside Main Street in the former town of Picher, Oklahoma, oriented southeast toward an abandoned baseball field and chat pile (CP037).

All photographs by S. Jerrod Smith, March 20, 2013. 


\section{Estimation of Volume and Mass and of Changes in Volume and Mass of Selected Chat Piles in the Picher Mining District, Ottawa County, Oklahoma, 2005-10}

By S. Jerrod Smith

Prepared in cooperation with the Bureau of Indian Affairs

Scientific Investigations Report 2013-5011 


\section{U.S. Department of the Interior \\ SALLY JEWELL, Secretary}

\section{U.S. Geological Survey \\ Suzette M. Kimball, Acting Director}

\section{U.S. Geological Survey, Reston, Virginia: 2013}

For more information on the USGS — the Federal source for science about the Earth, its natural and living resources, natural hazards, and the environment, visit http://www.usgs.gov or call 1-888-ASK-USGS.

For an overview of USGS information products, including maps, imagery, and publications, visit http://www.usgs.gov/pubprod

To order this and other USGS information products, visit http://store.usgs.gov

Any use of trade, firm, or product names is for descriptive purposes only and does not imply endorsement by the U.S. Government.

Although this information product, for the most part, is in the public domain, it also may contain copyrighted materials as noted in the text. Permission to reproduce copyrighted items must be secured from the copyright owner.

Suggested citation:

Smith, S.J., 2013, Estimation of volume and mass and of changes in volume and mass of selected chat piles in the Picher mining district, Ottawa County, Oklahoma, 2005-10: U.S. Geological Survey Scientific Investigations Report 2013-5011, 20 p., http://pubs.usgs.gov/sir/2013/5011/. 


\section{Contents}

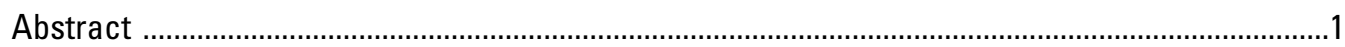

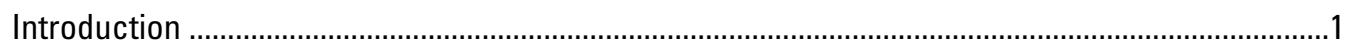

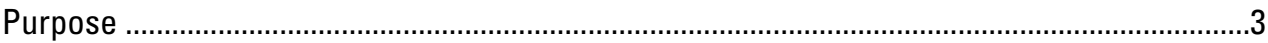

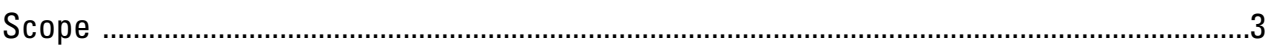

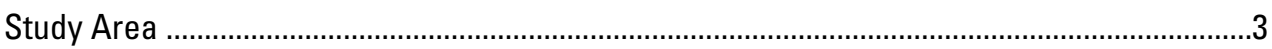

Methods for Estimating Volume and Mass of Selected Chat Piles ..................................................

Digital Elevation Models ...................................................................................................

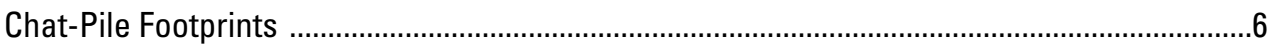

Chat-Pile Average Altitudes ..................................................................................................

Chat-Pile Base Altitudes and Chat-Pile Average Heights .......................................................6

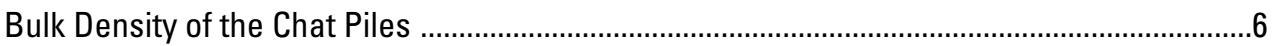

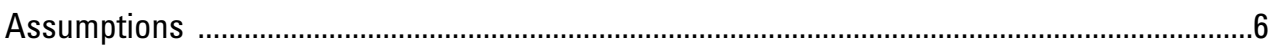

Estimation of 2005 and 2010 Chat-Pile Volumes and Masses .....................................................

Estimation of Changes in Chat Volumes and Masses for 2005 Through 2010 ................................10

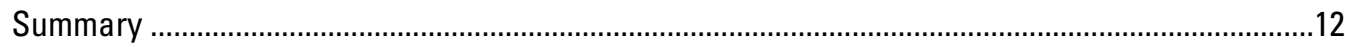

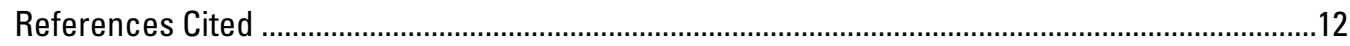

\section{Figures}

1. Aerial-photograph-draped, bare-earth light detection and ranging (lidar) survey scenes ( 2.5 times vertical exaggeration) showing selected chat piles on properties in the Picher mining district, Ottawa County, Oklahoma, in 2010 (property names are labeled on the scenes). $A$, View oriented northwest. $B$, View oriented south. $C$, View oriented southwest

2. Map showing locations and footprints of selected chat piles on properties in the Picher mining district, Ottawa County, Oklahoma

3. Theoretical chat-pile schematics showing data used to compute volumes of selected chat piles in the Picher mining district, Ottawa County, Oklahoma.

$A$, Map. $B$, Cross section

4. Map showing changes in land-surface altitude in the Picher mining district, Ottawa County, Oklahoma, 2005 through 2010

5. Boxplot showing bulk density of chat piles in the Picher mining district, Ottawa County, Oklahoma, 2005

6. Graphs showing estimates of chat-pile volume and mass for selected properties in the Picher mining district, Ottawa County, Oklahoma, 2005 and 2010

7. Graph showing estimates of volume and mass changes for selected chat piles on properties in the Picher mining district, Ottawa County, Oklahoma, 2005 through 2010 


\section{Tables}

1. Characteristics of selected chat piles on properties in the Picher mining district, Ottawa County, Oklahoma, and altitude statistics for selected chat piles, 2005 and 2010

2. Estimates of volume, mass, and change in volume and mass for selected chat piles on properties in the Picher mining district, Ottawa County, Oklahoma, 2005 through 2010

\section{Conversion Factors}

\section{Inch/Pound to SI}

\begin{tabular}{lcl}
\hline \multicolumn{1}{c}{ Multiply } & By & \multicolumn{1}{c}{ To obtain } \\
\hline foot $(\mathrm{ft})$ & Length & \\
mile $(\mathrm{mi})$ & 0.3048 & meter $(\mathrm{m})$ \\
yard $(\mathrm{yd})$ & 1.609 & kilometer $(\mathrm{km})$ \\
\hline & 0.9144 & meter $(\mathrm{m})$ \\
\hline acre & Area & \\
acre & 4,047 & square meter $\left(\mathrm{m}^{2}\right)$ \\
acre & 0.4047 & hectare $(\mathrm{ha})$ \\
acre & 0.4047 & square hectometer $\left(\mathrm{hm}^{2}\right)$ \\
square foot $\left(\mathrm{ft}^{2}\right)$ & 0.004047 & square kilometer $\left(\mathrm{km}^{2}\right)$ \\
square foot $\left(\mathrm{ft}^{2}\right)$ & 929.0 & square centimeter $\left(\mathrm{cm}^{2}\right)$ \\
square mile $\left(\mathrm{mi}^{2}\right)$ & 0.09290 & square meter $\left(\mathrm{m}^{2}\right)$ \\
square mile $\left(\mathrm{mi}^{2}\right)$ & 259.0 & hectare $(\mathrm{ha})$ \\
\hline & 2.590 & square kilometer $\left(\mathrm{km}^{2}\right)$ \\
\hline cubic foot $\left(\mathrm{ft}^{3}\right)$ & Volume & \\
cubic foot $\left(\mathrm{ft}^{3}\right)$ & 28.32 & cubic decimeter $\left(\mathrm{dm}^{3}\right)$ \\
cubic yard $\left(\mathrm{yd}^{3}\right)$ & 0.02832 & cubic meter $\left(\mathrm{m}^{3}\right)$ \\
\hline & 0.7646 & cubic meter $\left(\mathrm{m}^{3}\right)$ \\
\hline pound, avoirdupois $(\mathrm{lb})$ & Mass & \\
ton, short $(2,000 \mathrm{lb})$ & 0.4536 & kilogram $(\mathrm{kg})$ \\
\hline & 0.9072 & megagram $(\mathrm{Mg})$ \\
\hline pound per cubic foot $\left(\mathrm{lb} / \mathrm{ft}^{3}\right)$ & Density & \\
pound per cubic foot $\left(\mathrm{lb} / \mathrm{ft}^{3}\right)$ & 16.02 & kilogram per cubic meter $\left(\mathrm{kg} / \mathrm{m}^{3}\right)$ \\
ton, short $(2,000 \mathrm{lb})$ per cubic & 0.01602 & gram per cubic centimeter $\left(\mathrm{g} / \mathrm{cm}^{3}\right)$ \\
yard $\left(\right.$ ton $\left./ \mathrm{yd}^{3}\right)$ & 1.187 & megagram per cubic meter $\left(\mathrm{Mg} / \mathrm{m}^{3}\right)$ \\
\hline
\end{tabular}

Vertical coordinate information is referenced to the North American Vertical Datum of 1988 (NAVD 88).

Altitude, as used in this report, refers to distance above the vertical datum. 


\title{
Estimation of Volume and Mass and of Changes in Volume and Mass of Selected Chat Piles in the Picher Mining District, Ottawa County, Oklahoma, 2005-10
}

\author{
By S. Jerrod Smith
}

\section{Abstract}

From the 1890s through the 1970s the Picher mining district in northeastern Ottawa County, Oklahoma, was the site of mining and processing of lead and zinc ore. When mining ceased in about 1979, as much as 165-300 million tons of mine tailings, locally referred to as "chat," remained in the Picher mining district. Since 1979, some chat piles have been mined for aggregate materials and have decreased in volume and mass. Currently (2013), the land surface in the Picher mining district is covered by thousands of acres of chat, much of which remains on Indian trust land owned by allottees. The Bureau of Indian Affairs manages these allotted lands and oversees the sale and removal of chat from these properties. To help the Bureau of Indian Affairs better manage the sale and removal of chat, the U.S. Geological Survey, in cooperation with the Bureau of Indian Affairs, estimated the 2005 and 2010 volumes and masses of selected chat piles remaining on allotted lands in the Picher mining district. The U.S. Geological Survey also estimated the changes in volume and mass of these chat piles for the period 2005 through 2010.

The 2005 and 2010 chat-pile volume and mass estimates were computed for 34 selected chat piles on 16 properties in the study area. All computations of volume and mass were performed on individual chat piles and on groups of chat piles in the same property. The Sooner property had the greatest estimated volume (4.644 million cubic yards) and mass (5.253 \pm 0.473 million tons) of chat in 2010. Five of the selected properties (Sooner, Western, Lawyers, Skelton, and St. Joe) contained estimated chat volumes exceeding 1 million cubic yards and estimated chat masses exceeding 1 million tons in 2010. Four of the selected properties (Lucky Bill Humbah, Ta Mee Heh, Bird Dog, and St. Louis No. 6) contained estimated chat volumes of less than 0.1 million cubic yards and estimated chat masses of less than 0.1 million tons in 2010. The total volume of all selected chat piles was estimated to be 18.073 million cubic yards in 2005 and 16.171 million cubic yards in 2010. The total mass of all selected chat piles was estimated to be $20.445 \pm 1.840$ million tons in 2005 and $18.294 \pm 1.646$ million tons in 2010 .
All of the selected chat piles decreased in volume and mass for the period 2005 through 2010. Chat piles CP022 (Ottawa property) and CP013 (Sooner property) had some within-property chat-pile redistribution, with both chat piles having net decreases in volume and mass for the period 2005 through 2010. The Sooner property and the St. Joe property had the greatest volume (and mass) changes, with 1.266 million cubic yards and 0.217 million cubic yards $(1.432 \pm$ 0.129 million tons and $0.246 \pm 0.022$ million tons) of chat being removed, respectively. The chat removed from the Sooner and St. Joe properties accounts for about 78 percent of the chat removed from all selected chat piles and properties. The total volume and mass removed from all selected chat piles for the period 2005 through 2010 were estimated to be 1.902 million cubic yards and $2.151 \pm 0.194$ million tons, respectively.

\section{Introduction}

From the 1890s through the 1970s the Picher mining district (PMD) in northeastern Ottawa County, Oklahoma, was the site of mining and processing of lead and zinc ore (State of Oklahoma, 2000). Subsurface mines, some as deep as 400 feet ( $\mathrm{ft}$ ), supplied unprocessed ore to mills on the land surface. When mining ceased in about 1979, as much as 165-300 million tons of mine tailings, locally referred to as "chat," remained in the PMD (State of Oklahoma, 2000). The U.S. Army Corps of Engineers estimated that 75 million tons of mine tailings remained in the PMD in 2000 (State of Oklahoma, 2000). If an average bulk density of 83.8 pounds per cubic foot (lb/ft'; AATA International, Inc., 2005) or 1.1313 ton per cubic yard $\left(\mathrm{ton} / \mathrm{yd}^{3}\right)$ is assumed, 75 million tons corresponds to a volume of about 66.7 million cubic yards $\left(\mathrm{yd}^{3}\right)$ of chat.

A 2005 report classified the areas of remaining chat into three categories: chat piles, chat bases, and chat fines (AATA International, Inc., 2005). Chat piles are mounded areas of mine tailings that may be higher than $180 \mathrm{ft}$ above the surrounding terrain (fig. 1). Chat piles contain mostly 


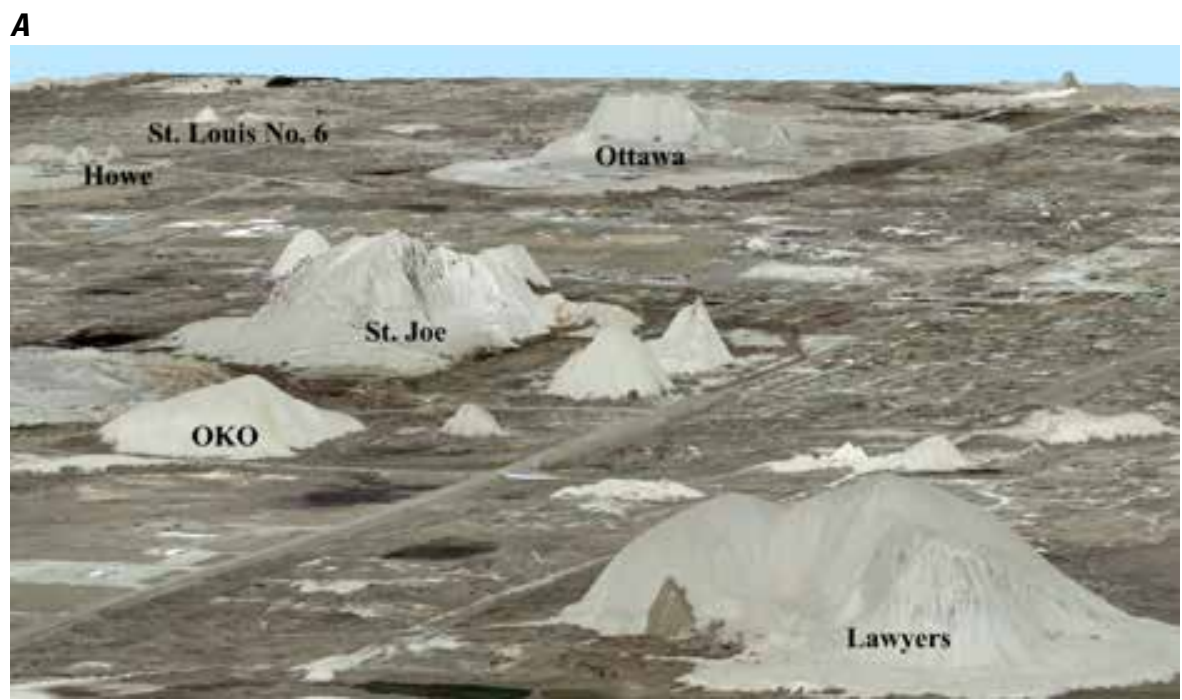

B

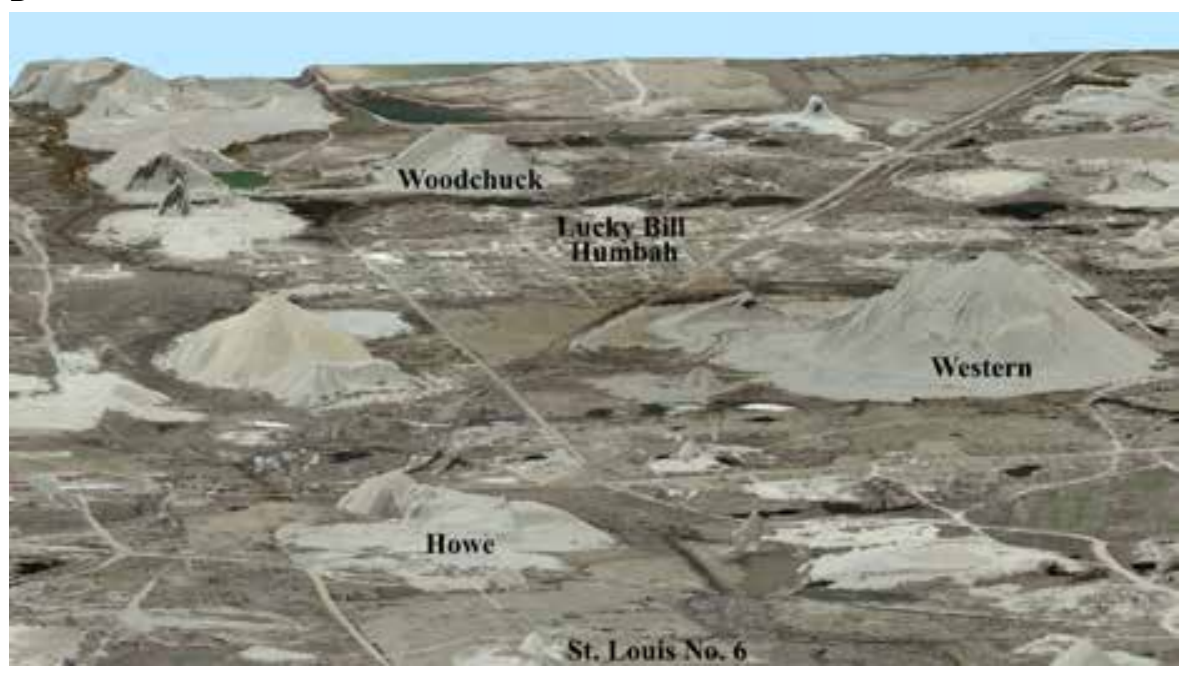

C

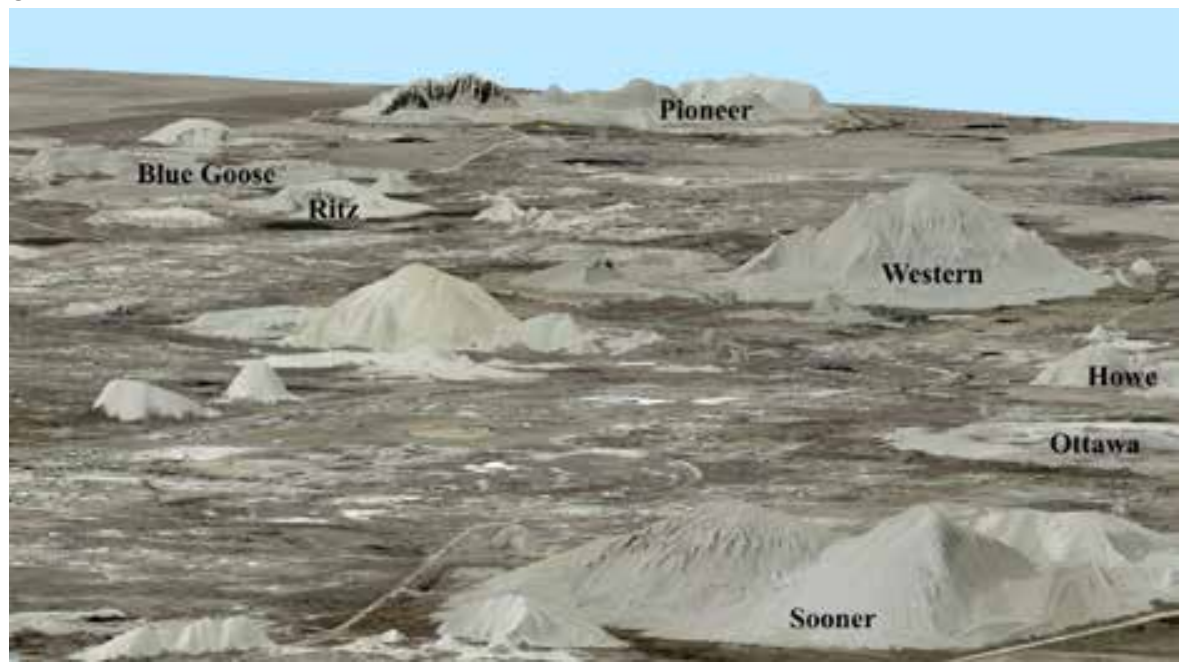

Figure 1. Aerial-photograph-draped, bare-earth light detection and ranging (lidar) survey scenes (2.5 times vertical exaggeration) showing selected chat piles on properties in the Picher mining district, Ottawa County, Oklahoma, in 2010 (property names are labeled on the scenes). $A$, View oriented northwest. $B$, View oriented south. $C$, View oriented southwest. 
gravel- to sand-sized material that has economic value, primarily as aggregate for road construction. Since 1979, some chat piles have been mined for aggregate materials and have decreased in volume and mass. AATA International, Inc. (2005), estimated that 31.2 million $\mathrm{yd}^{3}$ of chat remained in chat piles in 2004. As chat piles are removed for sale, chat bases are exposed. Chat bases are lower lying, level areas that were formerly covered by chat piles. Chat bases contain chat of unknown thickness and are of similar altitude to the surrounding terrain. AATA International, Inc. (2005), estimated that 6.71 million $\mathrm{yd}^{3}$ of chat remained in chat bases in 2004. The third category of chat, chat fines, contains mostly fine-sand-, silt-, and clay-sized particles. Chat fines are located adjacent to chat piles and are the remains of remilled chat piles; they were considered to contain too little coarse material to have economic value at the time of this report (2013). AATA International, Inc. (2005), estimated that 9.16 million $\mathrm{yd}^{3}$ of chat fines remained in 2004.

Currently (2013), the land surface in the PMD is covered by thousands of acres of chat, much of which remains on Indian trust land owned by allottees. The Bureau of Indian Affairs (BIA) manages these allotted lands and oversees the sale and removal of chat from these properties. To help the BIA better manage the sale and removal of chat, the U.S. Geological Survey (USGS), in cooperation with the BIA, estimated the 2005 and 2010 volumes and masses of selected chat piles remaining on allotted lands in the Picher mining district. The USGS also estimated the changes in volume and mass of these chat piles for the period 2005 through 2010.

\section{Purpose}

The purposes of this report are to present estimates of volume and mass computed for selected chat piles in 2005 and 2010 and to present estimates of changes in volume and mass for selected chat piles for the period 2005 through 2010. The report also documents data sources, assumptions, and methods that were used to estimate the volumes and masses of selected chat piles so that the computations can be repeated as new data become available. The chat-pile volume and mass estimates in this report may be used by the BIA and other stakeholders to estimate the economic value of remaining chat resources and assess offers and bids to purchase remaining chat resources.

\section{Scope}

This report contains volume and mass estimates of 34 selected chat piles on 16 BIA-managed properties in the PMD. Volume and mass estimates are reported for these selected chat piles only; no attempt was made to estimate the volume or mass of chat remaining in other chat piles, chat bases, or chat fines. Because of time and funding constraints, chat-pile volumes were estimated in a geographic information system by using aerially surveyed altitude data rather than by using ground-surveyed altitude data.

\section{Study Area}

The study area includes about 12 square miles $\left(\mathrm{mi}^{2}\right)$ of the PMD in northern Ottawa County, Oklahoma, near the former town of Picher (fig. 2). Where it is not covered by chat, the study area is relatively flat, and there is typically little change in altitude over short distances. At least 50 chat piles of various sizes have been identified in the study area (AATA International, Inc., 2005). Thirty-four of these chat piles were selected for analysis of volume and mass (fig. 2, table 1 at end of report). Each of these chat piles has a unique identification number and is associated with a property that may contain one or more distinct chat piles (AATA International, Inc., 2005); however, some property names used in this report were updated to names that are commonly used by the BIA (table 1). All computations of volume and mass were performed on individual chat piles and on groups of chat piles in the same property.

\section{Methods for Estimating Volume and Mass of Selected Chat Piles}

Several datasets were needed to estimate the volume and mass of the selected chat piles. Required datasets were (1) digital elevation models (DEMs) of the land surface in 2005 and 2010, (2) footprints of the selected chat piles, (3) the chat-pile average altitude in each footprint, (4) the base altitude of each chat pile, and (5) the bulk density measurements of the chat piles. The volumes of selected chat piles were computed as the chat-pile average height (the chatpile average altitude minus the chat-pile base altitude) times the chat-pile footprint area (fig. 3). The masses of selected chat piles were computed as the chat-pile volume times the average chat-pile bulk density.

\section{Digital Elevation Models}

Land-surface altitudes were determined by using 2005 and 2010 bare-earth DEMs developed from aerial-based light detection and ranging (lidar) surveys. The 2005 lidar survey was flown in March 2005 (Aero-Metric, Inc., 2005). The resulting 2005 bare-earth DEM had a horizontal resolution of $10 \mathrm{ft}(3.05$ meters $[\mathrm{m}])$ and a vertical precision of $0.01 \mathrm{ft}$ $(0.003 \mathrm{~m})$. The 2005 lidar survey also included acquisition of high-resolution $(0.5 \mathrm{ft})$ leaf-off aerial orthophotography for the study area (Aero-Metric, Inc., 2005). The 2010 lidar survey was flown on April 11, 2010 (Photo Science, Inc., 2010). The resulting 2010 bare-earth DEM had a horizontal resolution of $3.28 \mathrm{ft}(1 \mathrm{~m})$ and a vertical precision of $0.0328 \mathrm{ft}(0.01 \mathrm{~m})$. The lidar data were reprojected to Lambert Conformal Conic, Oklahoma State Plane North projection, and the 2005 DEM was resampled by using bilinear interpolation to match the extent and resolution of the 2010 DEM prior to analysis. 


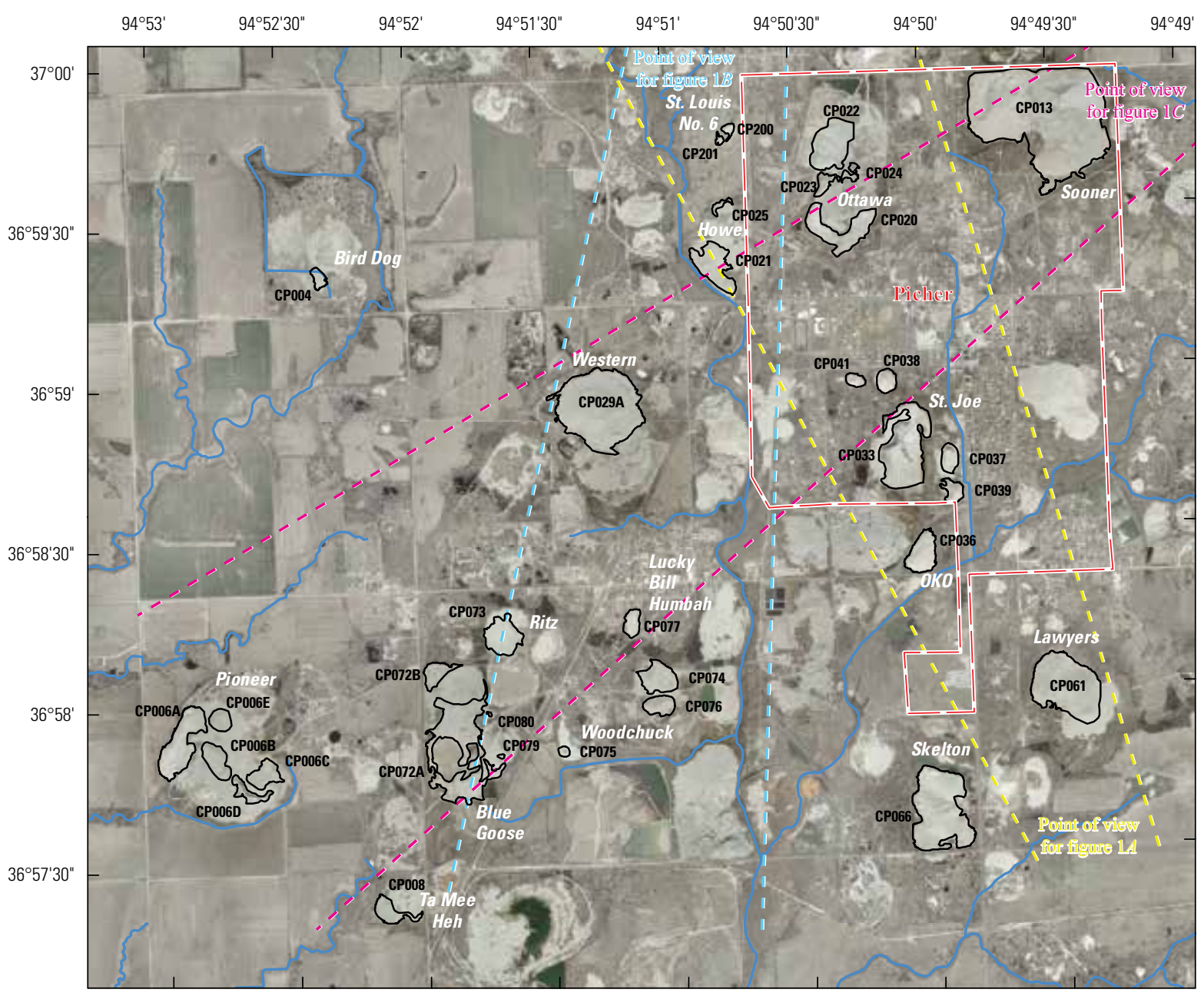

Base aerial photography from Aero-Metric, Inc., 2005

Municipal boundary from U.S. Census Bureau, 2000

Chat-pile boundaries modified from AATA International, Inc., 2005

Lambert Conformal Conic, Oklahoma State Plane North projection
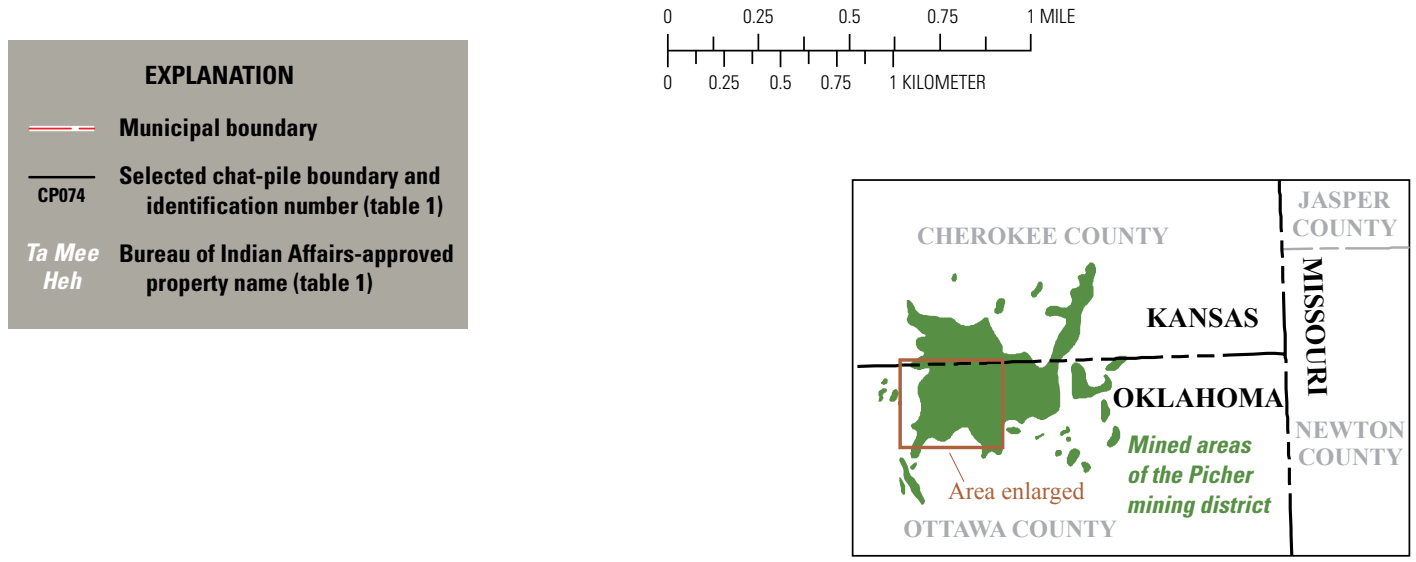

Figure 2. Locations and footprints of selected chat piles on properties in the Picher mining district, Ottawa County, Oklahoma. 


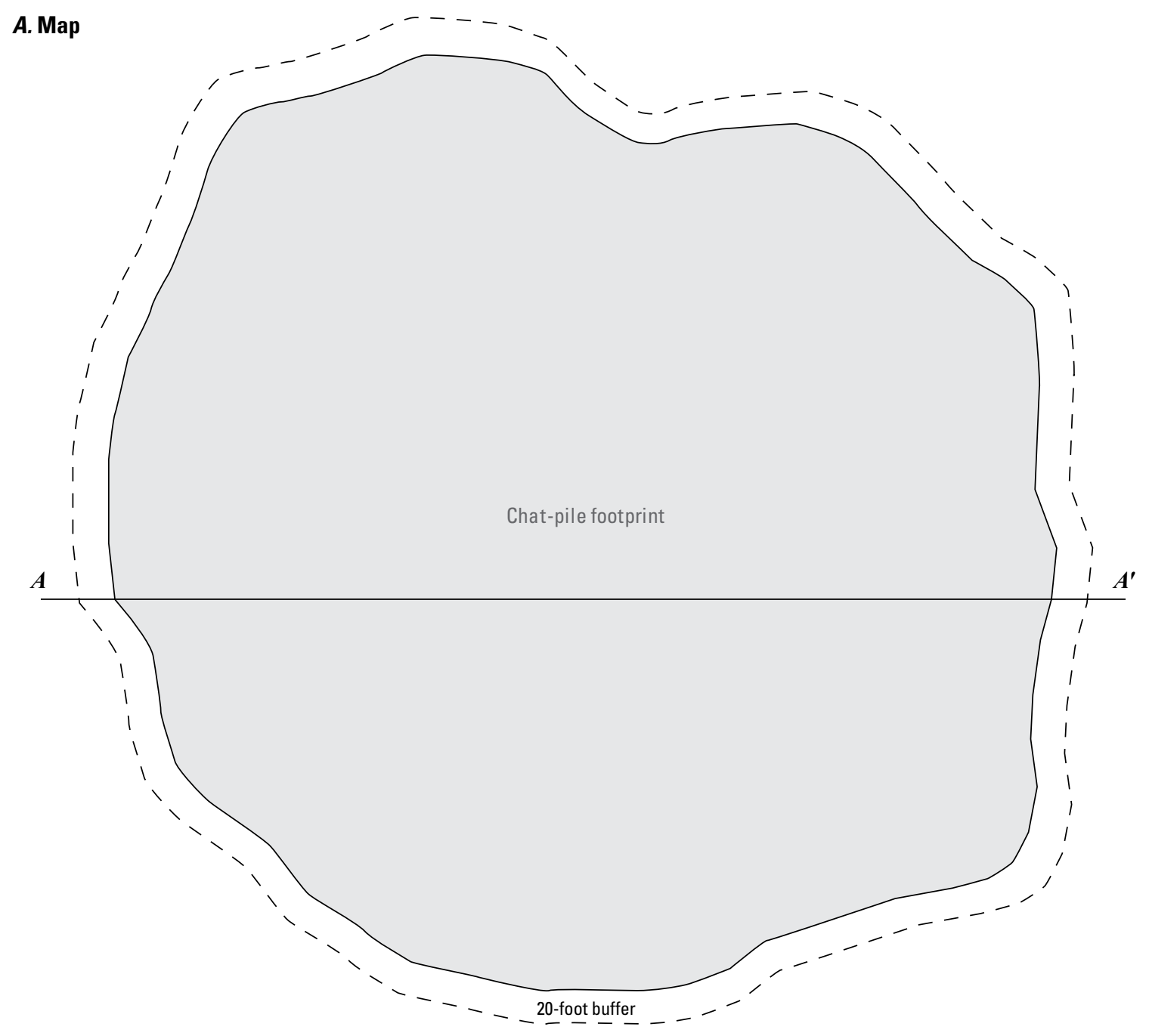

\section{B. Cross section}

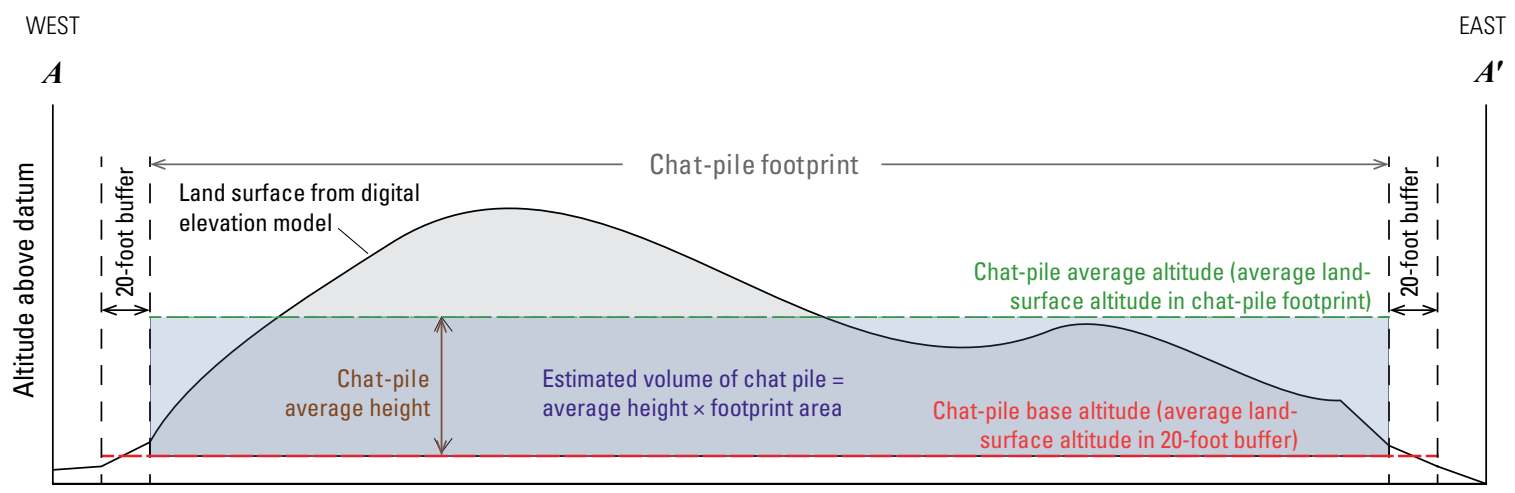

VERTICAL EXAGGERATION

Figure 3. Theoretical chat-pile schematics showing data used to compute volumes of selected chat piles in the Picher mining district, Ottawa County, Oklahoma. A, Map. B, Cross section. 


\section{Chat-Pile Footprints}

The chat-pile footprints were originally obtained from AATA International, Inc. (2005). The St. Louis No. 6 chat piles (CP200 and CP201), which had not been delineated by AATA International, Inc. (2005), were delineated in ESRI ArcGIS 10.0 software (Environmental Systems Research Institute, Inc., Redlands, Calif.) at a 1:1,200 scale by using high-resolution $(0.5 \mathrm{ft})$ aerial photographs and digital elevation data (Aero-Metric, Inc., 2005) acquired in March 2005. A preliminary, map-based assessment of land-surface altitude changes was necessary to ensure that the chat-pile footprints covered all areas where chat was removed or redistributed. A map (fig. 4) showing changes in land-surface altitude for the period 2005 through 2010 was created by subtracting the 2005 DEM from the 2010 DEM by using the ArcGIS Raster Calculator tool (ESRI, Inc., 2012a) and rounding to the nearest foot. Yellow and red hues (negative changes in altitude) on the map indicate removal of material (as much as $-99 \mathrm{ft}$ ), and blue hues (positive changes in altitude) indicate accumulation of material (as much as $59 \mathrm{ft}$ ) during the period 2005 through 2010 (fig. 4). For clarity, areas with minimal land-surface altitude changes (between 1 and $-1 \mathrm{ft}$ ) are not shown on figure 4. The Sooner and Ottawa properties, for which both red and blue areas are indicated (fig. 4), show redistribution of chat as it was removed from one area, sorted or screened, and placed in another area. On the basis of the changes in altitude (fig. 4), the chat-pile footprints for CP022 (Ottawa property) and $\mathrm{CP} 013$ (Sooner property) were modified slightly from AATA International, Inc. (2005), to include areas of chat-pile redistribution. All chat-pile footprints and property names were reviewed and approved by the BIA (S. Beets, Realty Specialist, U.S. Bureau of Indian Affairs, written commun., 2012). Areas of selected chat-pile footprints ranged from 0.13 to 97.37 acres (table 1).

\section{Chat-Pile Average Altitudes}

The minimum, maximum, and average altitudes in the chat-pile footprint were extracted from the 2005 and 2010 DEMs by using the ArcGIS Zonal Statistics as Table tool (ESRI, Inc., 2012b) (table 1). The average altitude in the chat-pile footprint was used to represent the chat-pile average altitude in computations of chat-pile volume (fig. 3).

\section{Chat-Pile Base Altitudes and Chat-Pile Average Heights}

Determination of the base altitudes of the selected chat piles was accomplished in ArcGIS by using the Buffer tool (ESRI, Inc., 2012c) to delineate a 20-ft buffer around each BIA-approved chat-pile footprint (fig. 3). The minimum, maximum, and average altitudes in the 20 -ft chat-pile buffer were extracted from the 2005 and 2010 DEMs by using the ArcGIS Zonal Statistics as Table tool (ESRI, Inc., 2012b) (table 1). The base of each chat pile was assumed to be a horizontal plane with an altitude equal to the 2010 average altitude in the chat-pile buffer (table 1). The 2010 DEM was used to establish the chat-pile base altitude because the 2010 DEM was of finer resolution than the 2005 DEM. For each selected chat pile, the chat-pile base altitude was subtracted from the 2005 and 2010 chat-pile average altitudes to compute chat-pile average height in 2005 and 2010 (fig. 3, table 2 at end of report).

\section{Bulk Density of the Chat Piles}

Bulk density (the mass of a substance divided by its bulk volume) is used to describe the density of a substance that is a complex mixture of materials that may contain air or pore space. AATA International, Inc. (2005), collected and analyzed 41 bulk-density samples from 41 different chat piles in the PMD. The AATA International, Inc. (2005), bulk-density measurements ranged from $70.0 \mathrm{lb} / \mathrm{ft}^{3}\left(0.9450\right.$ ton/yd $\left.\mathrm{d}^{3}\right)$ to $97.6 \mathrm{lb} / \mathrm{ft}^{3}\left(1.3176 \mathrm{ton} / \mathrm{yd}^{3}\right)$ and averaged $83.8 \mathrm{lb} / \mathrm{ft}^{3}(1.1313$ ton/yd $\mathrm{d}^{3}$ ) (fig. 5). The 10th and 90 th percentiles of bulk density measurements were $76.6 \mathrm{lb} / \mathrm{ft}^{3}\left(1.0341 \mathrm{ton} / \mathrm{yd}^{3}\right)$ and $91.6 \mathrm{lb} /$ $\mathrm{ft}^{3}\left(1.2366\right.$ ton/yd $\left.\mathrm{d}^{3}\right)$, respectively (fig. 5). For this report, an average bulk density of $1.1313 \mathrm{ton} / \mathrm{yd}^{3}$ was used to convert chat-pile volume to chat-pile mass (table 2). The 10th and 90th percentiles of bulk densities reported by AATA International, Inc. (2005), which correspond to about plus or minus 9 percent of the average bulk density, were used to assign error margins to all masses computed in this report.

\section{Assumptions}

Several computational assumptions were necessary because of uncertainty associated with the footprints and compositions of the chat piles. All computations presented in this report assumed the following:

1. the chat-pile footprints encompassed the entire chat-pile resource in 2005 and 2010 ,

2. the bases of the chat piles were planar and horizontal,

3. the average altitude in a 20 - $\mathrm{ft}$ buffer surrounding each chat pile represented a reasonable estimate of the altitude of the chat-pile base,

4. differences in DEM horizontal resolution and vertical precision were not a source of systematic error in the volume computations, and

5. the average bulk density of each chat pile was 1.1313 ton $/ \mathrm{yd}^{3}$.

Any decreases in chat-pile volume and mass were expected to be caused by removal of material by humans. Decreases in chat-pile volume and mass also may occur, however, as a result of natural processes such as settling, erosion by water and wind (an Enhanced Fujita [EF]-4 tornado 


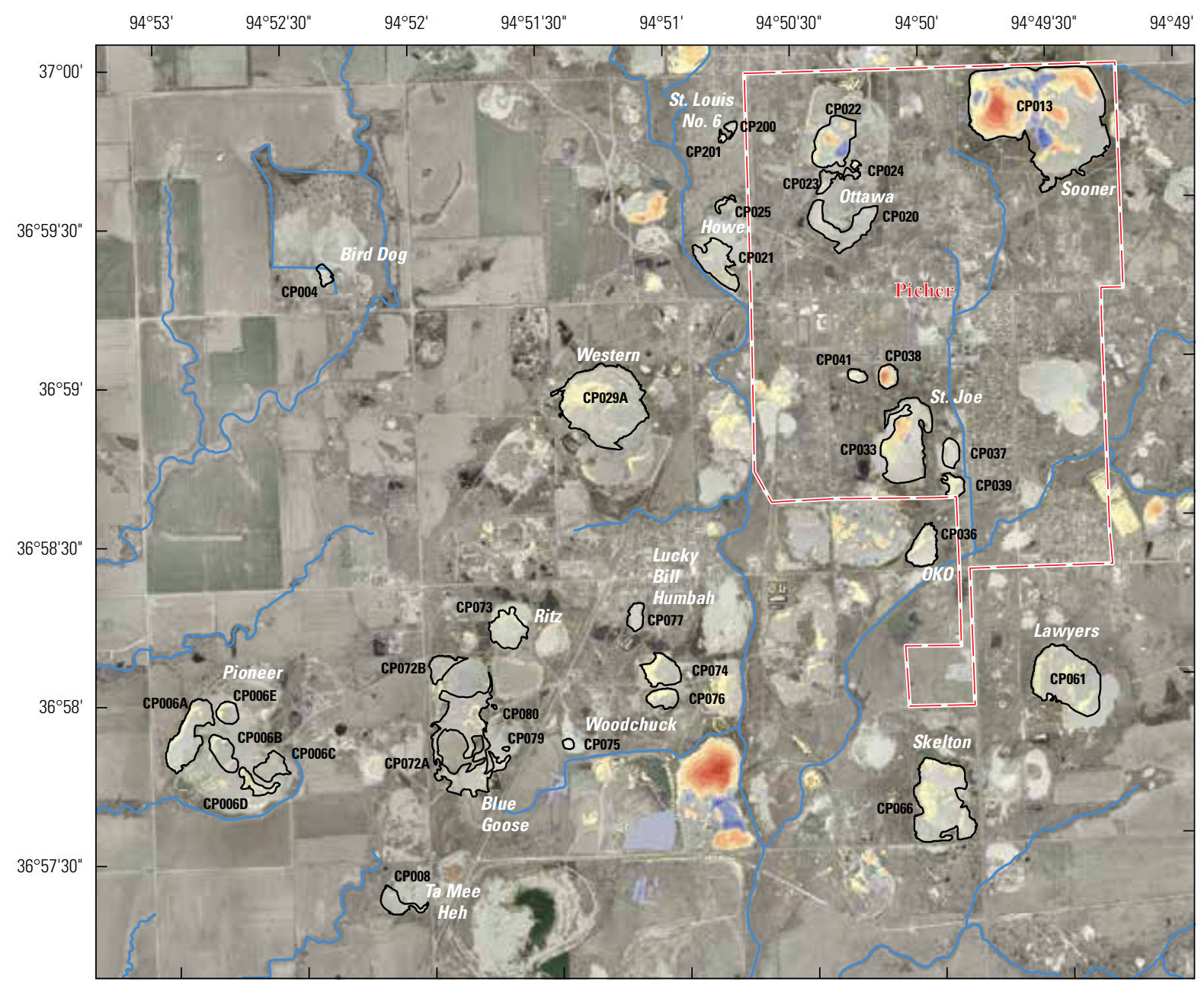

Base aerial photography from Aero-Metric, Inc., 2005

Municipal boundary from U.S. Census Bureau, 2000

Chat-pile boundaries modified from AATA International, Inc., 2005

Lambert Conformal Conic, Oklahoma State Plane North projection

\begin{tabular}{|c|c|}
\hline EXPLANATION \\
Change in altitude, in feet, 2005-10 \\
-99 to -90 \\
-89 to -70 \\
-69 to -50 \\
-49 to -30 \\
-29 to -10 \\
-9 to -2 \\
-1 to 1 (not shown) \\
2 to 9 \\
10 to 29 \\
30 to 49 \\
50 to 58 \\
\hline Municipal boundary \\
\hline CP074 \\
\hline Selected chat-pile boundary and \\
identification number (table 1) \\
\hline Heh \\
\hline Bureau of Indian Affairs-approved \\
property name (table 1)
\end{tabular}
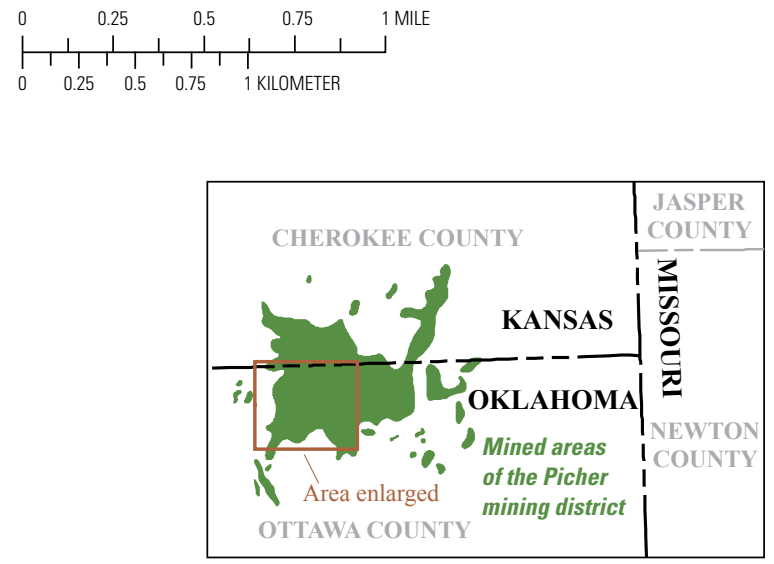

Figure 4. Changes in land-surface altitude in the Picher mining district, Ottawa County, Oklahoma, 2005 through 2010. 


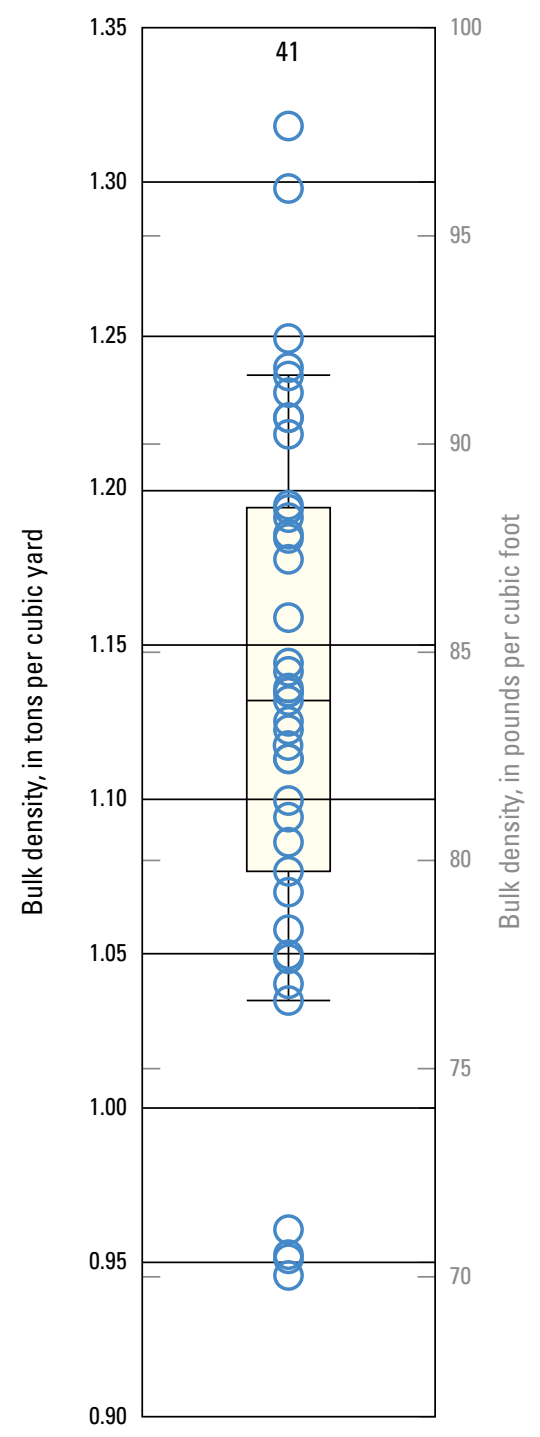

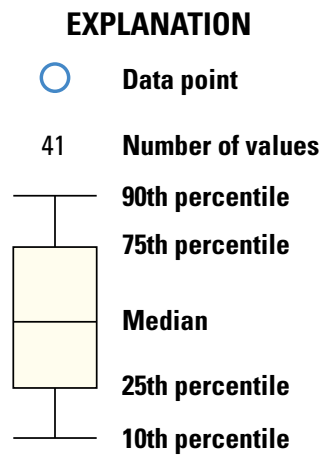

Data from AATA International, Inc., 2005

Figure 5. Bulk density of chat piles in the Picher mining district, Ottawa County, Oklahoma, 2005.

destroyed many structures and vegetated areas in the vicinity of the St. Joe chat piles on May 10, 2008 [Aber and Aber, 2009]), or subsurface mine collapse and subsidence. No attempt was made in this report to differentiate between causes of chat-pile volume and mass changes.

\section{Estimation of 2005 and 2010 Chat-Pile Volumes and Masses}

The 2005 and 2010 chat-pile volume estimates were computed for the 34 chat piles on the 16 properties by multiplying the average chat-pile height by the chat-pile area and converting to units of cubic yards (table 2). For convenience, volume and mass estimates discussed in this report have been rounded to the nearest $1,000 \mathrm{yd}^{3}(0.001$ million $\left.\mathrm{yd}^{3}\right)$ and the nearest 1,000 tons ( 0.001 million tons), respectively. The Sooner property chat pile (CP013) had the greatest estimated volume (5.910 million $\mathrm{yd}^{3}$ in 2005 and

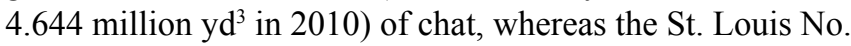
6 property (chat piles CP200 and CP201) had the smallest

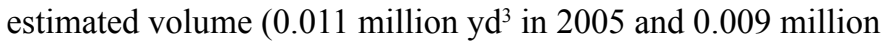
$\mathrm{yd}^{3}$ in 2010) of chat. Five of the selected properties (Sooner, Western, Lawyers, Skelton, and St. Joe) contained estimated chat volumes exceeding 1 million $\mathrm{yd}^{3}$ in 2005 and 2010 (fig. 6, table 2). Four of the selected properties (Lucky Bill Humbah, Ta Mee Heh, Bird Dog, and St. Louis No. 6) contained estimated chat volumes of less than 0.1 million $\mathrm{yd}^{3}$ in 2005 and 2010 (fig. 6, table 2). The total volume of all selected chat piles was estimated to be 18.073 million $\mathrm{yd}^{3}$ in 2005 and 16.171 million $\mathrm{yd}^{3}$ in 2010 . 


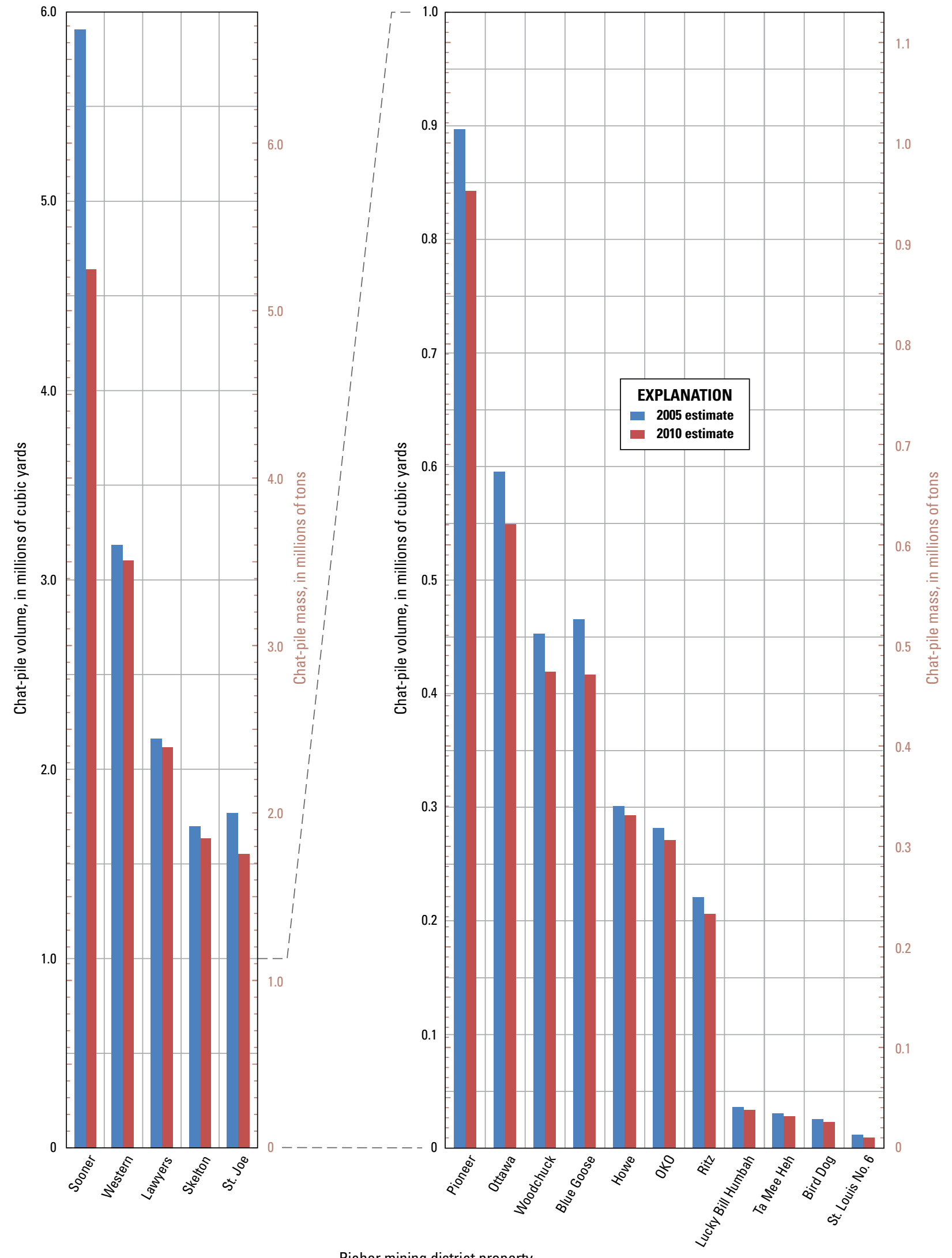

Picher mining district property

Figure 6. Estimates of chat-pile volume and mass for selected properties in the Picher mining district, Ottawa County, 0 klahoma, 2005 and 2010. 
The 2005 and 2010 chat-pile mass estimates were computed for the 34 chat piles on the 16 properties by multiplying the chat-pile volume by an average bulk density of $1.1313 \mathrm{ton} / \mathrm{yd}^{3}$ (fig. 6, table 2). The Sooner property chat pile (CP013) had the greatest estimated mass $(6.686 \pm 0.602$ million tons in 2005 and $5.253 \pm 0.473$ million tons in 2010) of chat, whereas the St. Louis No. 6 property (chat piles CP200 and CP201) had the smallest estimated mass $(0.013 \pm$ 0.001 million tons in 2005 and $0.010 \pm 0.0009$ million tons in 2010) of chat. Six of the selected properties (Sooner, Western, Lawyers, Skelton, St. Joe, and Pioneer) contained estimated chat masses exceeding 1 million tons in 2005, and five of the selected properties (Sooner, Western, Lawyers, Skelton, and St. Joe) contained estimated chat masses exceeding 1 million tons in 2010 (fig. 6, table 2). Four of the selected properties (Lucky Bill Humbah, Ta Mee Heh, Bird Dog, and St. Louis No. 6) contained estimated chat masses of less than 0.1 million tons in 2005 and 2010 (fig. 6, table 2). The total mass of all selected chat piles was estimated to be $20.445 \pm 1.840$ million tons in 2005 and $18.294 \pm 1.646$ million tons in 2010 .

\section{Estimation of Changes in Chat Volumes and Masses for 2005 Through 2010}

Changes in volume and mass estimates were computed by subtracting the 2005 volume and mass estimates from the
2010 volume and mass estimates (table 2 ). Negative values indicate a loss in volume and mass during the period 2005 through 2010. The chat-pile footprint areas and base altitudes were not changed for the period 2005 through 2010, so all changes in volume and mass resulted from changes in chatpile surface altitudes (figs. 4 and 7).

All of the selected chat piles decreased in volume and mass for the period 2005 through 2010 (table 2). Chat piles CP022 (Ottawa property) and CP013 (Sooner property) had some within-property chat-pile redistribution (fig. 4), with both chat piles having net decreases in volume and mass for the period 2005 through 2010 (table 2). The Sooner property and the St. Joe property had the greatest volume (and mass) changes, with 1.266 million $\mathrm{yd}^{3}$ and 0.217 million $\mathrm{yd}^{3}$ (1.432 \pm 0.129 million tons and $0.246 \pm 0.022$ million tons) of chat being removed, respectively (fig. 7, table 2). The chat removed from the Sooner and St. Joe properties accounts for about 78 percent of chat removed from all selected chat piles. The Sooner property had the greatest percent volume change with -21.43 percent change from the 2005 estimated volume (fig. 7, table 2). The Ta Mee Heh, Lucky Bill Humbah, Bird Dog, and St. Louis No. 6 properties had the smallest volume changes, each with less than 0.003 million $\mathrm{yd}^{3}$ of chat being removed (fig. 7, table 2). The total volume and mass removed from all selected chat piles for the period 2005 through 2010 were estimated to be 1.902 million $\mathrm{yd}^{3}$ and $2.151 \pm 0.194$ million tons, respectively. 


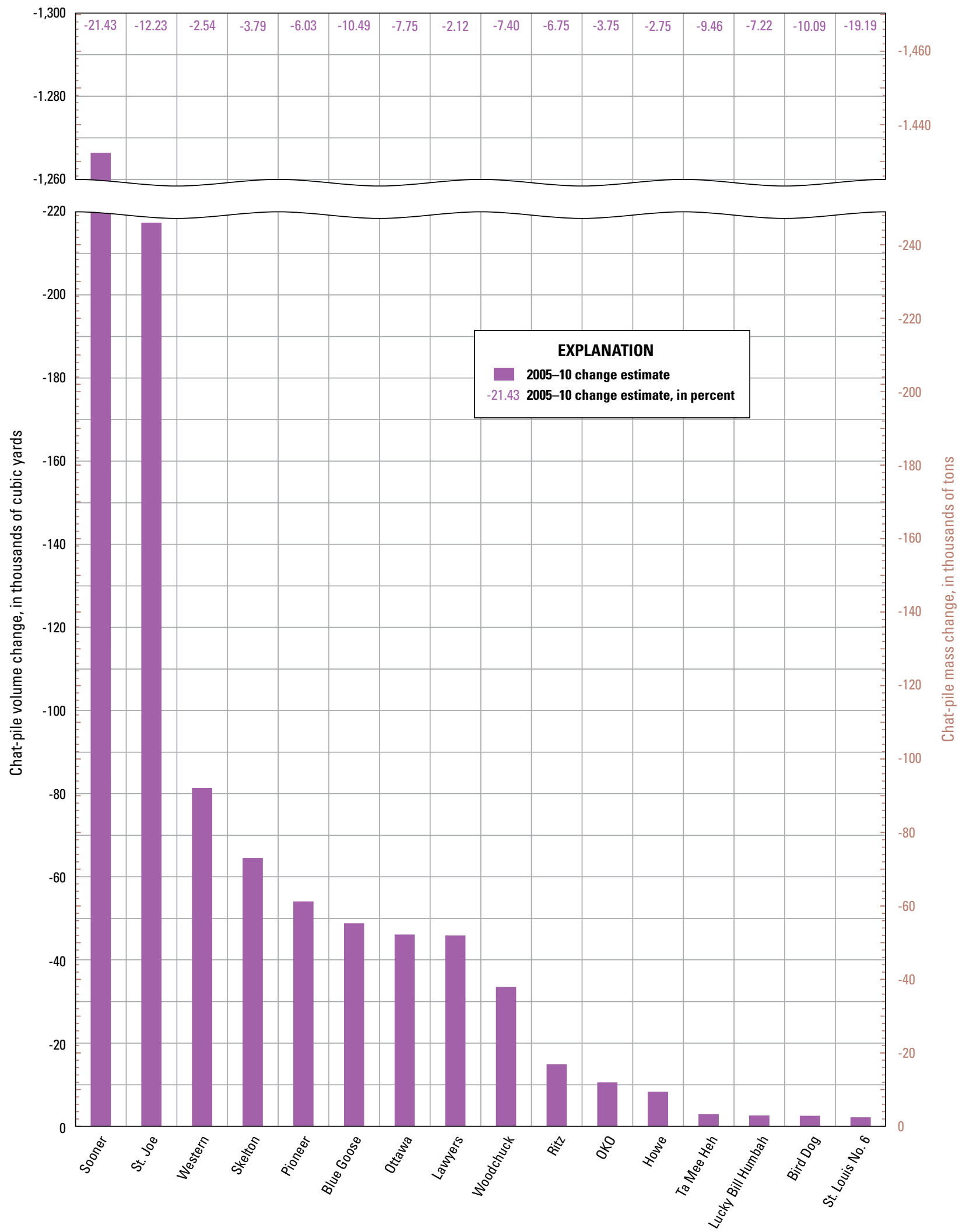

Picher mining district property

Figure 7. Estimates of volume and mass changes for selected chat piles on properties in the Picher mining district, Ottawa County, Oklahoma, 2005 through 2010. 


\section{Summary}

From the 1890s through the 1970s the Picher mining district (PMD) in northeastern Ottawa County, Oklahoma, was the site of mining and processing of lead and zinc ore. When mining ceased in about 1979, as much as 165-300 million tons of mine tailings, locally referred to as "chat," remained in the PMD. Since 1979, some chat piles have been mined for aggregate materials and have decreased in volume and mass. Currently (2013), thousands of acres of land surface in the PMD are covered by chat, much of which remains on Indian trust land owned by allottees. The Bureau of Indian Affairs (BIA) manages these allotted lands and oversees the sale and removal of chat from these properties. To help the BIA better manage the sale and removal of chat, the U.S. Geological Survey (USGS), in cooperation with the BIA, estimated the 2005 and 2010 volumes and masses of selected chat piles remaining on allotted lands in the Picher mining district. The USGS also estimated the changes in volume and mass of these chat piles for the period 2005 through 2010.

Several datasets were needed to estimate the volume and mass of the selected chat piles. Required datasets were (1) digital elevation models (DEMs) of the land surface in 2005 and 2010, (2) footprints of the selected chat piles, (3) the chat-pile average altitude in each footprint, (4) the base altitude of each chat pile, and (5) the bulk density measurements of the chat piles. The volumes of selected chat piles were computed as the chat-pile average height (the chatpile average altitude minus the chat-pile base altitude) times the chat-pile footprint area. The masses of selected chat piles were computed as the chat-pile volume times the average chatpile bulk density.

The 2005 and 2010 chat-pile volume and mass estimates were computed for 34 selected chat piles on 16 properties in the study area. All computations of volume and mass were performed on individual chat piles and on groups of chat piles in the same property. The Sooner property (chat pile CP013) had the greatest estimated volume (4.644 million cubic yards $\left.\left[\mathrm{yd}^{3}\right]\right)$ and mass $(5.253 \pm 0.473$ million tons) of chat in 2010 . Five of the selected properties (Sooner, Western, Lawyers, Skelton, and St. Joe) contained estimated chat volumes exceeding 1 million $\mathrm{yd}^{3}$ and estimated chat masses exceeding 1 million tons in 2010. Four of the selected properties (Lucky Bill Humbah, Ta Mee Heh, Bird Dog, and St. Louis No. 6) contained estimated chat volumes of less than 0.1 million $\mathrm{yd}^{3}$ and estimated chat masses of less than 0.1 million tons in 2010. The total volume of all selected chat piles was estimated

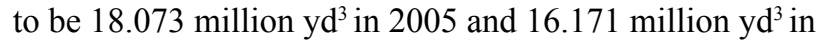
2010. The total mass of all selected chat piles was estimated to be $20.445 \pm 1.840$ million tons in 2005 and $18.294 \pm 1.646$ million tons in 2010 .

All of the selected chat piles decreased in volume and mass for the period 2005 through 2010. Chat piles CP022 (Ottawa property) and CP013 (Sooner property) had some within-property chat-pile redistribution, with both chat piles having net decreases in volume and mass for the period 2005 through 2010. The Sooner property and the St. Joe property had the greatest volume (and mass) changes, with 1.266 million $\mathrm{yd}^{3}$ and 0.217 million $\mathrm{yd}^{3}(1.432 \pm 0.129$ million tons and $0.246 \pm 0.022$ million tons) of chat being removed, respectively. The chat removed from the Sooner and St. Joe properties accounts for about 78 percent of chat removed from all selected chat piles. The total volume and mass removed from all selected chat piles for the period 2005 through 2010

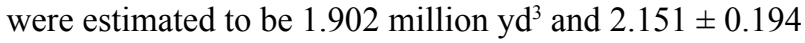
million tons, respectively.

\section{References Cited}

AATA International, Inc., 2005, DRAFT-Remedial Investigation Report Tar Creek OU4 RI/FS Program: accessed December 4, 2012, at http://www.deq.state.ok.us/ lpdnew/Tarcreek/Redesign/Superfund\%20Documents/ RI\%20Reports/Draft_RI_Report_December_2005.pdf, $178 \mathrm{p}$.

Aber, J.S., and Aber, S.W., 2009, Picher, Oklahoma-Legacy of mining: accessed December 4, 2012, at http://www. geospectra.net/kite/picher/picher.htm.

Aero-Metric, Inc., 2005, Aerial lidar and photography survey of the Tar Creek area, Oklahoma, March 2005: Prepared for the U.S. Geological Survey Oklahoma Water Science Center.

Brichta, L.C., 1960, Catalog of recorded exploration drilling and mine workings, Tri-State zinc-lead district, Missouri, Kansas, and Oklahoma: U.S. Bureau of Mines Information Circular IC7993, $13 \mathrm{p}$.

ESRI, Inc., 2012a, ArcGIS resource center-Raster calculator (spatial analyst): ArcGIS 10, accessed December 4, 2012, at http://help.arcgis.com/en/arcgisdesktop/10.0/help/index. html\#//009z000000z7000000.htm.

ESRI, Inc., 2012b, ArcGIS resource center-Zonal statistics as table (spatial analyst): ArcGIS 10, accessed December 4, 2012, at http://help.arcgis.com/en/arcgisdesktop/10.0/help/ index.html\#//009z000000w8000000.htm.

ESRI, Inc., 2012c, ArcGIS resource center-Buffer (analysis): ArcGIS 10, accessed December 4, 2012, at http:/help.arcgis.com/en/arcgisdesktop/10.0/help/index. html\#//000800000019000000.

Photo Science, Inc., 2010, Aerial lidar survey of the Tar Creek area, Oklahoma, April 2010: Prepared for the U.S. Geological Survey Oklahoma Water Science Center.

State of Oklahoma, 2000, Governor Frank Keating's Tar Creek Superfund Task Force-Final report: Oklahoma City, Okla., Office of the Secretary of Environment, accessed December 4, 2012, at http://www.environment.ok.gov/documents/ TarCk/TarCreekTFFinalReport.pdf, 26 .

U.S. Census Bureau, 2000, Census 2000-Incorporated places/Census designated places cartographic boundary files: accessed December 4, 2012, at http://www.census.gov/ geo/www/cob/pl2000.html. 
Table 1. Characteristics of selected chat piles on properties in the Picher mining district, Ottawa County, Oklahoma, and altitude statistics for selected chat piles, 2005 and 2010

[BIA, Bureau of Indian Affairs; $\mathrm{yd}^{2}$, square yards; ft, feet; --, none]

\begin{tabular}{|c|c|c|c|c|c|c|c|c|}
\hline \multirow{2}{*}{$\begin{array}{l}\text { BIA-approved } \\
\text { property name }\end{array}$} & \multirow{2}{*}{$\begin{array}{c}\text { Alternate property } \\
\text { name (AATA } \\
\text { International, } \\
\text { Inc., 2005) }\end{array}$} & \multirow{2}{*}{$\begin{array}{l}\text { Chat-pile } \\
\text { identifi- } \\
\text { cation } \\
\text { number }^{1}\end{array}$} & \multirow{2}{*}{$\begin{array}{c}\text { Legal description } \\
\text { (section-township-range) }\end{array}$} & \multicolumn{2}{|c|}{ Chat-pile footprint area } & \multicolumn{3}{|c|}{$\begin{array}{c}\text { Chat-pile altitude } 2010 \\
\text { (Photo Science, Inc., 2010) }\end{array}$} \\
\hline & & & & (acres) & $\left(y d^{2}\right)$ & $\begin{array}{l}\text { Minimum } \\
\text { (ft) }\end{array}$ & $\begin{array}{l}\text { Maximum } \\
(\mathrm{ft})\end{array}$ & $\begin{array}{c}\text { Average } \\
\text { (ft) }\end{array}$ \\
\hline Bird Dog & -- & CP004 & 13-T29N-R22E & 1.80 & 8,716 & 831.37 & 865.96 & 846.41 \\
\hline Blue Goose & -- & CP072A & 30-T29N-R23E & 29.39 & 142,246 & 829.08 & 886.03 & 846.28 \\
\hline Blue Goose & -- & СР072B & $30-T 29 N-R 23 E$ & 4.12 & 19,923 & 836.99 & 857.99 & 844.29 \\
\hline Blue Goose & -- & СР079 & $30-\mathrm{T} 29 \mathrm{~N}-\mathrm{R} 23 \mathrm{E}$ & 0.19 & 934 & 832.61 & 842.76 & 837.54 \\
\hline Blue Goose & -- & CP080 & $30-T 29 N-R 23 E$ & 0.13 & 622 & 835.51 & 847.16 & 839.56 \\
\hline Blue Goose subtotal & & & & 33.83 & 163,725 & & & \\
\hline Howe & -- & CP021 & $17-\mathrm{T} 29 \mathrm{~N}-\mathrm{R} 23 \mathrm{E}$ & 10.37 & 50,174 & 811.78 & 872.20 & 834.03 \\
\hline Howe & -- & $\mathrm{CP} 025$ & $17-T 29 N-R 23 E$ & 0.93 & 4,511 & 818.48 & 842.33 & 827.53 \\
\hline Howe subtotal & & & & 11.30 & 54,685 & & & \\
\hline Lawyers & -- & CP061 & $28-\mathrm{T} 29 \mathrm{~N}-\mathrm{R} 23 \mathrm{E}$ & 28.67 & 138,765 & 825.46 & 966.34 & 878.80 \\
\hline Lucky Bill Humbah & -- & СР077 & $30-\mathrm{T} 29 \mathrm{~N}-\mathrm{R} 23 \mathrm{E}$ & 3.03 & 14,649 & 811.84 & 840.21 & 823.49 \\
\hline OKO & -- & CP036 & 20-T29N-R23E & 7.72 & 37,357 & 806.40 & 877.92 & 832.78 \\
\hline Ottawa & -- & СР020 & $17-\mathrm{T} 29 \mathrm{~N}-\mathrm{R} 23 \mathrm{E}$ & 12.45 & 60,258 & 833.37 & 848.71 & 841.31 \\
\hline Ottawa & -- & ${ }^{2} \mathrm{CP} 022$ & $17-\mathrm{T} 29 \mathrm{~N}-\mathrm{R} 23 \mathrm{E}$ & 13.48 & 65,247 & 841.92 & 918.04 & 865.67 \\
\hline Ottawa & -- & CP023 & $17-T 29 N-R 23 E$ & 2.32 & 11,222 & 836.44 & 878.48 & 851.19 \\
\hline Ottawa & -- & $\mathrm{CP} 024$ & $17-T 29 N-R 23 E$ & 1.38 & 6,680 & 840.31 & 886.99 & 850.75 \\
\hline Ottawa subtotal & & & & 29.63 & 143,406 & & & \\
\hline Pioneer & -- & CP006A & 25-T29N-R22E & 14.36 & 69,509 & 822.21 & 887.75 & 845.69 \\
\hline Pioneer & -- & CP006B & $25-\mathrm{T} 29 \mathrm{~N}-\mathrm{R} 22 \mathrm{E}$ & 5.66 & 27,372 & 828.50 & 893.13 & 859.44 \\
\hline Pioneer & -- & CP006C & $25-\mathrm{T} 29 \mathrm{~N}-\mathrm{R} 22 \mathrm{E}$ & 5.06 & 24,493 & 829.93 & 846.65 & 838.67 \\
\hline Pioneer & -- & CP006D & $25-\mathrm{T} 29 \mathrm{~N}-\mathrm{R} 22 \mathrm{E}$ & 3.33 & 16,122 & 832.89 & 906.62 & 866.13 \\
\hline Pioneer & -- & СР006E & $25-\mathrm{T} 29 \mathrm{~N}-\mathrm{R} 22 \mathrm{E}$ & 3.17 & 15,348 & 833.37 & 882.41 & 856.33 \\
\hline Pioneer subtotal & & & & 31.58 & 152,844 & & & \\
\hline
\end{tabular}


Table 1. Characteristics of selected chat piles on properties in the Picher mining district, Ottawa County, Oklahoma, and altitude statistics for selected chat piles, 2005 and 2010.-Continued

[BIA, Bureau of Indian Affairs; $\mathrm{yd}^{2}$, square yards; ft, feet; --, none]

\begin{tabular}{|c|c|c|c|c|c|c|c|c|}
\hline \multirow{2}{*}{$\begin{array}{l}\text { BIA-approved } \\
\text { property name }\end{array}$} & \multirow{2}{*}{$\begin{array}{l}\text { Alternate property } \\
\text { name (AATA } \\
\text { International, } \\
\text { Inc., 2005) }\end{array}$} & \multirow{2}{*}{$\begin{array}{l}\text { Chat-pile } \\
\text { identifi- } \\
\text { cation } \\
\text { number' }\end{array}$} & \multirow{2}{*}{$\frac{\text { Legal description }}{\text { (section-township-range) }}$} & \multicolumn{2}{|c|}{ Chat-pile footprint area } & \multicolumn{3}{|c|}{$\begin{array}{c}\text { Chat-pile altitude } 2010 \\
\text { (Photo Science, Inc., 2010) }\end{array}$} \\
\hline & & & & (acres) & $\left(y d^{2}\right)$ & $\underset{(\mathrm{ft})}{\text { Minimum }}$ & $\underset{\text { (ft) }}{\text { Maximum }}$ & $\begin{array}{c}\text { Average } \\
\text { (ft) }\end{array}$ \\
\hline Ritz & -- & CP073 & 30-T29N-R23E & 8.72 & 42,193 & 827.24 & 877.57 & 847.98 \\
\hline Skelton & -- & CP066 & 29-T29N-R23E & 31.15 & 150,750 & 817.65 & 960.09 & 857.86 \\
\hline Sooner & -- & ${ }^{2} \mathrm{CP} 013$ & $16-T 29 N-R 23 E$ & 97.37 & 471,287 & 828.92 & 967.88 & 869.53 \\
\hline St. Joe & -- & CP033 & 20-T29N-R23E & 24.75 & 119,807 & 822.49 & 952.10 & 859.58 \\
\hline St. Joe & Slim Jim & CP037 & $20-\mathrm{T} 29 \mathrm{~N}-\mathrm{R} 23 \mathrm{E}$ & 3.34 & 16,179 & 814.01 & 895.99 & 838.45 \\
\hline St. Joe & Premier & CP039 & 20-T29N-R23E & 2.96 & 14,319 & 814.12 & 893.37 & 844.85 \\
\hline St. Joe & Vintage (East) & СР038 & 20-T29N-R23E & 3.17 & 15,349 & 825.02 & 882.02 & 847.63 \\
\hline St. Joe & Vintage (West) & $\mathrm{CP} 041$ & 20-T29N-R23E & 1.71 & 8,257 & 825.94 & 887.97 & 844.40 \\
\hline St. Joe subtotal & & & & 35.93 & 173,911 & & & \\
\hline St. Louis No. 6 & -- & ${ }^{3} \mathrm{CP} 200$ & 17-T29N-R23E & 0.93 & 4,512 & 827.47 & 840.26 & 833.05 \\
\hline St. Louis No. 6 & -- & ${ }^{3} \mathrm{CP} 201$ & $17-T 29 N-R 23 E$ & 0.53 & 2,552 & 825.44 & 858.96 & 834.83 \\
\hline St. Louis No. 6 subtotal & & & & 1.46 & 7,063 & & & \\
\hline Ta Mee Heh & Tam-ah-hah & CP008 & $36-T 29 N-R 22 E$ & 4.70 & 22,746 & 821.93 & 845.38 & 829.44 \\
\hline Western & Anna Beaver & CP029A & $19-\mathrm{T} 29 \mathrm{~N}-\mathrm{R} 23 \mathrm{E}$ & 43.87 & 212,349 & 827.93 & $1,007.09$ & 879.77 \\
\hline Woodchuck & -- & CP074 & $30-T 29 N-R 23 E$ & 7.30 & 35,323 & 810.62 & 895.25 & 841.17 \\
\hline Woodchuck & -- & СР076 & 30-T29N-R23E & 4.19 & 20,268 & 812.80 & 886.78 & 835.28 \\
\hline Woodchuck & -- & СР075 & 30-T29N-R23E & 0.78 & 3,796 & 822.85 & 874.18 & 837.95 \\
\hline Woodchuck subtotal & & & & 12.27 & 59,387 & & & \\
\hline TOTAL & & & & 383.02 & $1,853,834$ & & & \\
\hline
\end{tabular}


Table 1. Characteristics of selected chat piles on properties in the Picher mining district, Ottawa County, Oklahoma, and altitude statistics for selected chat piles, 2005 and 2010.-Continued

[BIA, Bureau of Indian Affairs; $\mathrm{yd}^{2}$, square yards; ft, feet; --, none]

\begin{tabular}{|c|c|c|c|c|c|c|c|c|c|c|c|}
\hline \multirow{3}{*}{$\begin{array}{l}\text { BIA-approved } \\
\text { property name }\end{array}$} & \multirow{3}{*}{$\begin{array}{c}\text { Chat-pile } \\
\text { identifi- } \\
\text { cation } \\
\text { number }^{1}\end{array}$} & \multirow{2}{*}{\multicolumn{3}{|c|}{$\begin{array}{l}\text { Chat-pile altitude } 2005 \\
\text { (Aero-Metric, Inc., 2005) }\end{array}$}} & \multirow{3}{*}{$\begin{array}{c}\text { Chat-pile } \\
\text { relief (ft) } \\
2010\end{array}$} & \multicolumn{6}{|c|}{ Chat-pile buffer altitude } \\
\hline & & & & & & \multicolumn{3}{|c|}{2010 (Photo Science, Inc., 2010) } & \multicolumn{3}{|c|}{2005 (Aero-Metric, Inc., 2005) } \\
\hline & & $\underset{\text { (ft) }}{\text { Minimum }}$ & $\begin{array}{l}\text { Maximum } \\
\text { (ft) }\end{array}$ & $\begin{array}{c}\text { Average } \\
\text { (ft) }\end{array}$ & & $\begin{array}{l}\text { Minimum } \\
\text { (ft) }\end{array}$ & $\begin{array}{l}\text { Maximum } \\
\text { (ft) }\end{array}$ & $\begin{array}{c}\text { Average } \\
\text { (ft) }\end{array}$ & $\underset{\text { (ft) }}{\text { Minimum }}$ & $\begin{array}{l}\text { Maximum } \\
\text { (ft) }\end{array}$ & $\begin{array}{c}\text { Average } \\
\text { (ft) }\end{array}$ \\
\hline Bird Dog & CP004 & 831.54 & 866.73 & 847.28 & 34.59 & 830.47 & 849.29 & 838.67 & 830.78 & 850.41 & 839.25 \\
\hline Blue Goose & CP072A & 828.15 & 886.69 & 847.14 & 56.95 & 827.36 & 856.03 & 837.61 & 828.28 & 869.11 & 838.40 \\
\hline Blue Goose & CP072B & 838.00 & 860.08 & 845.41 & 21.00 & 835.27 & 858.87 & 843.73 & 836.63 & 859.83 & 844.77 \\
\hline Blue Goose & СР079 & 832.98 & 844.66 & 838.31 & 10.15 & 832.24 & 841.89 & 833.52 & 832.71 & 843.69 & 834.40 \\
\hline Blue Goose & CP080 & 835.75 & 854.73 & 841.34 & 11.65 & 835.11 & 837.59 & 836.15 & 835.17 & 840.63 & 836.85 \\
\hline Howe & СР021 & 811.34 & 872.00 & 834.43 & 60.42 & 810.35 & 860.07 & 817.07 & 810.26 & 860.12 & 817.25 \\
\hline Howe & CP025 & 819.38 & 842.78 & 828.57 & 23.85 & 818.41 & 826.92 & 821.54 & 818.73 & 833.14 & 822.25 \\
\hline Lawyers & CP061 & 825.15 & 967.46 & 879.79 & 140.88 & 823.63 & 876.90 & 833.00 & 823.85 & 877.58 & 833.69 \\
\hline Lucky Bill Humbah & CP077 & 812.01 & 840.61 & 824.02 & 28.36 & 811.77 & 823.12 & 816.70 & 811.61 & 824.51 & 817.36 \\
\hline $\mathrm{OKO}$ & CP036 & 806.62 & 878.39 & 833.63 & 71.52 & 805.77 & 817.57 & 811.02 & 806.31 & 820.29 & 811.69 \\
\hline Ottawa & CP020 & 833.51 & 849.10 & 841.63 & 15.35 & 833.17 & 845.33 & 837.42 & 833.26 & 845.20 & 837.78 \\
\hline Ottawa & ${ }^{2} \mathrm{CP} 022$ & 842.14 & 918.94 & 867.13 & 76.12 & 840.80 & 858.79 & 846.52 & 840.74 & 859.40 & 846.23 \\
\hline Ottawa & СР023 & 836.57 & 879.19 & 852.24 & 42.04 & 836.28 & 848.08 & 841.10 & 836.23 & 850.22 & 841.36 \\
\hline Ottawa & CP024 & 840.44 & 887.12 & 852.52 & 46.68 & 839.97 & 850.14 & 843.26 & 840.21 & 851.94 & 843.72 \\
\hline Pioneer & CP006A & 823.14 & 887.62 & 846.42 & 65.54 & 819.99 & 844.64 & 828.40 & 820.18 & 844.91 & 828.76 \\
\hline Pioneer & СР006B & 828.30 & 894.03 & 860.16 & 64.63 & 827.65 & 859.75 & 839.36 & 827.81 & 859.52 & 839.55 \\
\hline Pioneer & СР006C & 830.60 & 846.52 & 838.80 & 16.72 & 829.71 & 840.94 & 833.04 & 829.52 & 840.71 & 832.94 \\
\hline Pioneer & CP006D & 831.40 & 906.92 & 870.08 & 73.73 & 830.30 & 882.37 & 841.74 & 829.87 & 884.92 & 841.72 \\
\hline Pioneer & CP006E & 833.59 & 882.76 & 857.95 & 49.04 & 833.05 & 858.98 & 840.26 & 833.43 & 859.63 & 841.38 \\
\hline
\end{tabular}


Table 1. Characteristics of selected chat piles on properties in the Picher mining district, Ottawa County, Oklahoma, and altitude statistics for selected chat piles, 2005 and 2010.-Continued

[BIA, Bureau of Indian Affairs; $\mathrm{yd}^{2}$, square yards; ft, feet; --, none]

\begin{tabular}{|c|c|c|c|c|c|c|c|c|c|c|c|}
\hline \multirow{3}{*}{$\begin{array}{l}\text { BIA-approved } \\
\text { property name }\end{array}$} & \multirow{3}{*}{$\begin{array}{l}\text { Chat-pile } \\
\text { identifi- } \\
\text { cation } \\
\text { number }\end{array}$} & \multirow{2}{*}{\multicolumn{3}{|c|}{$\begin{array}{l}\text { Chat-pile altitude } 2005 \\
\text { (Aero-Metric, Inc., 2005) }\end{array}$}} & \multirow{3}{*}{$\begin{array}{c}\text { Chat-pile } \\
\text { relief (ft) } \\
2010\end{array}$} & \multicolumn{6}{|c|}{ Chat-pile buffer altitude } \\
\hline & & & & & & \multicolumn{3}{|c|}{2010 (Photo Science, Inc., 2010) } & \multicolumn{3}{|c|}{2005 (Aero-Metric, Inc., 2005) } \\
\hline & & $\underset{(f t)}{M}$ & $\underset{\text { (ft) }}{\text { Maximum }}$ & $\begin{array}{l}\text { Average } \\
\text { (ft) }\end{array}$ & & $\underset{(f t)}{\text { Minimum }}$ & $\begin{array}{c}\text { Maximum } \\
\text { (ft) }\end{array}$ & $\begin{array}{c}\text { Average } \\
\text { (ft) }\end{array}$ & $\underset{\text { (ft) }}{\text { Minimum }}$ & $\underset{\text { (ft) }}{\text { Maximum }}$ & $\begin{array}{c}\text { Average } \\
\text { (ft) }\end{array}$ \\
\hline Ritz & CP073 & 827.56 & 878.18 & 849.04 & 50.33 & 826.59 & 856.47 & 833.35 & 826.97 & 857.42 & 834.34 \\
\hline Skelton & CP066 & 818.15 & 960.92 & 859.15 & 142.44 & 813.99 & 857.18 & 825.27 & 816.41 & 857.83 & 826.27 \\
\hline Sooner & ${ }^{2} \mathrm{CP} 013$ & 828.71 & 975.99 & 877.59 & 138.96 & 828.77 & 855.69 & 839.97 & 827.53 & 856.13 & 840.17 \\
\hline St. Joe & CP033 & 822.33 & 971.20 & 862.51 & 129.61 & 820.53 & 855.58 & 829.90 & 820.88 & 854.53 & 830.29 \\
\hline St. Joe & CP037 & 813.93 & 896.84 & 839.38 & 81.98 & 813.62 & 835.65 & 818.91 & 813.77 & 840.42 & 819.83 \\
\hline St. Joe & CP039 & 814.48 & 893.69 & 846.84 & 79.25 & 812.14 & 857.49 & 820.06 & 812.30 & 858.80 & 820.86 \\
\hline St. Joe & СР038 & 823.75 & 914.37 & 863.68 & 57.00 & 822.68 & 835.13 & 826.62 & 822.83 & 838.38 & 826.99 \\
\hline St. Joe & CP041 & 826.55 & 887.89 & 845.75 & 62.03 & 825.48 & 833.77 & 828.66 & 825.85 & 834.44 & 828.93 \\
\hline St. Louis No. 6 & ${ }^{3} \mathrm{CP} 200$ & 827.76 & 840.64 & 833.54 & 12.79 & 826.87 & 835.23 & 830.64 & 827.62 & 835.57 & 831.02 \\
\hline St. Louis No. 6 & ${ }^{3} \mathrm{CP} 201$ & 826.28 & 859.57 & 836.48 & 33.52 & 824.72 & 833.06 & 828.47 & 825.02 & 833.49 & 828.71 \\
\hline Ta Mee Heh & CP008 & 822.23 & 845.61 & 829.82 & 23.45 & 821.71 & 836.95 & 825.80 & 822.07 & 837.26 & 826.07 \\
\hline Western & CP029A & 828.67 & $1,008.20$ & 880.92 & 179.16 & 826.71 & 846.17 & 835.67 & 827.41 & 846.54 & 836.28 \\
\hline Woodchuck & СР074 & 811.62 & 895.98 & 843.02 & 84.63 & 809.09 & 849.43 & 818.00 & 809.41 & 849.73 & 818.63 \\
\hline Woodchuck & СР076 & 811.26 & 887.42 & 836.63 & 73.98 & 812.60 & 825.15 & 815.56 & 811.49 & 825.46 & 816.35 \\
\hline Woodchuck & CP075 & 824.00 & 877.75 & 840.00 & 51.33 & 821.71 & 831.34 & 827.38 & 822.43 & 831.50 & 828.15 \\
\hline
\end{tabular}

${ }^{1}$ Chat-pile identification number from AATA International, Inc. (2005), unless otherwise noted.

${ }^{2}$ Chat-pile boundary modified from AATA International, Inc. (2005).

${ }^{3} \mathrm{New}$ chat-pile identification number and boundary were generated for this report. 
Table 2. Estimates of volume, mass, and change in volume and mass for selected chat piles on properties in the Picher mining district, 0ttawa County, 0klahoma, 2005 through 2010.

[BIA, Bureau of Indian Affairs; $\mathrm{yd}^{2}$, square yards; $\mathrm{yd}^{3}$, cubic yards; ft, feet; --, none; \pm , plus or minus]

\begin{tabular}{|c|c|c|c|c|c|c|c|c|c|c|}
\hline \multirow{3}{*}{$\begin{array}{l}\begin{array}{l}\text { BIA-approved } \\
\text { property name }\end{array} \\
\text { Bird Dog }\end{array}$} & \multirow{3}{*}{$\begin{array}{c}\text { Alternate } \\
\text { property } \\
\text { name (AATA } \\
\text { International, } \\
\text { Inc., 2005) } \\
--\end{array}$} & \multirow{3}{*}{$\begin{array}{l}\text { Chat-pile } \\
\text { identi- } \\
\text { fication } \\
\text { number }\end{array}$} & \multirow{3}{*}{$\begin{array}{c}\begin{array}{c}\text { Legal description } \\
\text { (section- } \\
\text { township-range) }\end{array} \\
13-\mathrm{T} 29 \mathrm{~N}-\mathrm{R} 22 \mathrm{E}\end{array}$} & \multicolumn{2}{|c|}{$\begin{array}{c}\text { Chat-pile } \\
\text { footprint area }\end{array}$} & \multirow{3}{*}{$\begin{array}{c}\text { Bulk } \\
\text { density (AATA } \\
\text { International, Inc., } \\
\begin{array}{c}\text { 2005) average } \\
\text { (ton/yd }\end{array} \\
1.1313\end{array}$} & \multicolumn{4}{|c|}{$\begin{array}{l}\text { Estimates of volume and mass } \\
2005\end{array}$} \\
\hline & & & & (acres) & $\left(y d^{2}\right)$ & & \multirow{2}{*}{$\begin{array}{c}\begin{array}{c}\text { Average } \\
\text { height } \\
\text { (ft) }\end{array} \\
8.61\end{array}$} & \multirow{2}{*}{$\begin{array}{c}\begin{array}{c}\text { Volume } \\
\left(y^{3}\right)\end{array} \\
25,020\end{array}$} & \multicolumn{2}{|c|}{$\begin{array}{l}\text { Mass } \\
\text { (tons) }\end{array}$} \\
\hline & & & & 1.80 & 8,716 & & & & 28,305 & $\pm \mathbf{2 , 5 4 7}$ \\
\hline Blue Goose & -- & СР072A & 30-T29N-R23E & 29.39 & 142,246 & 1.1313 & 9.53 & 451,850 & 511,178 & $\pm 46,006$ \\
\hline Blue Goose & -- & СР072B & $30-T 29 N-R 23 E$ & 4.12 & 19,923 & 1.1313 & 1.68 & 11,150 & 12,614 & $\pm 1,135$ \\
\hline Blue Goose & -- & СР079 & $30-T 29 N-R 23 E$ & 0.19 & 934 & 1.1313 & 4.79 & 1,492 & 1,687 & \pm 152 \\
\hline Blue Goose & -- & СР080 & 30-T29N-R23E & 0.13 & 622 & 1.1313 & 5.19 & 1,078 & 1,219 & \pm 110 \\
\hline Blue Goose subtotal & & & & 33.83 & 163,725 & & & 465,569 & 526,699 & $\pm \mathbf{4 7 , 4 0 3}$ \\
\hline Howe & -- & СР021 & 17-T29N-R23E & 10.37 & 50,174 & 1.1313 & 17.36 & 290,333 & 328,453 & $\pm 29,561$ \\
\hline Howe & -- & СР025 & $17-T 29 N-R 23 E$ & 0.93 & 4,511 & 1.1313 & 7.04 & 10,578 & 11,967 & $\pm 1,077$ \\
\hline Howe subtotal & & & & 11.30 & 54,685 & & & 300,911 & 340,421 & $\pm \mathbf{3 0 , 6 3 8}$ \\
\hline Lawyers & -- & СР061 & 28-T29N-R23E & 28.67 & 138,765 & 1.1313 & 46.80 & $2,164,522$ & $2,448,724$ & $\pm \mathbf{2 2 0}, \mathbf{3 8 5}$ \\
\hline Lucky Bill Humbah & -- & СР077 & $30-T 29 N-R 23 E$ & 3.03 & 14,649 & 1.1313 & 7.32 & 35,747 & 40,440 & $\pm \mathbf{3 , 6 4 0}$ \\
\hline OKO & -- & СР036 & $20-T 29 N-R 23 E$ & 7.72 & 37,357 & 1.1313 & 22.60 & 281,461 & 318,417 & $\pm \mathbf{2 8 , 6 5 7}$ \\
\hline Ottawa & -- & СР020 & $17-T 29 N-R 23 E$ & 12.45 & 60,258 & 1.1313 & 4.22 & 84,725 & 95,850 & $\pm 8,626$ \\
\hline Ottawa & -- & ${ }^{2} \mathrm{CP} 022$ & $17-T 29 N-R 23 E$ & 13.48 & 65,247 & 1.1313 & 20.61 & 448,287 & 507,147 & $\pm 45,643$ \\
\hline Ottawa & -- & СР023 & $17-T 29 N-R 23 E$ & 2.32 & 11,222 & 1.1313 & 11.14 & 41,673 & 47,145 & $\pm 4,243$ \\
\hline Ottawa & -- & СР024 & $17-T 29 N-R 23 E$ & 1.38 & 6,680 & 1.1313 & 9.26 & 20,612 & 23,318 & $\pm 2,099$ \\
\hline Ottawa subtotal & & & & 29.63 & 143,406 & & & $\mathbf{5 9 5 , 2 9 7}$ & 673,460 & $\pm 60,611$ \\
\hline Pioneer & -- & CP006A & $25-\mathrm{T} 29 \mathrm{~N}-\mathrm{R} 22 \mathrm{E}$ & 14.36 & 69,509 & 1.1313 & 18.02 & 417,496 & 472,314 & $\pm 42,508$ \\
\hline Pioneer & -- & СР006B & $25-\mathrm{T} 29 \mathrm{~N}-\mathrm{R} 22 \mathrm{E}$ & 5.66 & 27,372 & 1.1313 & 20.80 & 189,796 & 214,716 & $\pm 19,324$ \\
\hline Pioneer & -- & СР006C & $25-\mathrm{T} 29 \mathrm{~N}-\mathrm{R} 22 \mathrm{E}$ & 5.06 & 24,493 & 1.1313 & 5.76 & 46,991 & 53,161 & $\pm 4,784$ \\
\hline Pioneer & -- & CP006D & $25-\mathrm{T} 29 \mathrm{~N}-\mathrm{R} 22 \mathrm{E}$ & 3.33 & 16,122 & 1.1313 & 28.34 & 152,304 & 172,301 & $\pm 15,507$ \\
\hline Pioneer & -- & CP006E & $25-\mathrm{T} 29 \mathrm{~N}-\mathrm{R} 22 \mathrm{E}$ & 3.17 & 15,348 & 1.1313 & 17.69 & 90,491 & 102,372 & $\pm 9,213$ \\
\hline Pioneer subtotal & & & & 31.58 & 152,844 & & & 897,078 & $1,014,864$ & $\pm \mathbf{9 1 , 3 3 8}$ \\
\hline
\end{tabular}


Table 2. Estimates of volume, mass, and change in volume and mass for selected chat piles on properties in the Picher mining district, 0ttawa County, 0klahoma, 2005 through 2010.-Continued

[BIA, Bureau of Indian Affairs; $\mathrm{yd}^{2}$, square yards; $\mathrm{yd}^{3}$, cubic yards; $\mathrm{ft}$, feet; --, none; \pm , plus or minus]

\begin{tabular}{|c|c|c|c|c|c|c|c|c|c|c|}
\hline \multirow{2}{*}{$\begin{array}{l}\text { BIA-approved } \\
\text { property name }\end{array}$} & \multirow{2}{*}{$\begin{array}{c}\text { Alternate } \\
\text { property } \\
\text { name (AATA } \\
\text { International, } \\
\text { Inc., 2005) }\end{array}$} & \multirow{2}{*}{$\begin{array}{c}\text { Chat-pile } \\
\text { identi- } \\
\text { fication } \\
\text { number }^{1}\end{array}$} & \multirow{2}{*}{$\begin{array}{l}\text { Legal description } \\
\text { (section- } \\
\text { township-range) }\end{array}$} & \multicolumn{2}{|c|}{$\begin{array}{c}\text { Chat-pile } \\
\text { footprint area }\end{array}$} & \multirow{2}{*}{$\begin{array}{c}\text { Bulk } \\
\text { density (AATA } \\
\text { International, Inc., } \\
\begin{array}{c}\text { 2005) average } \\
\left.\text { (ton/yd } \text { s }^{3}\right)\end{array}\end{array}$} & \multicolumn{4}{|c|}{$\begin{array}{l}\text { Estimates of volume and mass } \\
22005\end{array}$} \\
\hline & & & & (acres) & $\left(y d^{2}\right)$ & & $\begin{array}{c}\text { Average } \\
\text { height } \\
\text { (ft) }\end{array}$ & $\begin{array}{c}\text { Volume } \\
\left(y d^{3}\right)\end{array}$ & & $\begin{array}{l}\text { ass } \\
\text { ns) }\end{array}$ \\
\hline Ritz & -- & СР073 & 30-T29N-R23E & 8.72 & 42,193 & 1.1313 & 15.69 & 220,711 & 249,690 & $\pm 22,472$ \\
\hline Skelton & -- & СР066 & 29-T29N-R23E & 31.15 & 150,750 & 1.1313 & 33.87 & $1,702,074$ & $1,925,557$ & $\pm 173,300$ \\
\hline Sooner & -- & ${ }^{2} \mathrm{CP} 013$ & $16-\mathrm{T} 29 \mathrm{~N}-\mathrm{R} 23 \mathrm{E}$ & 97.37 & 471,287 & 1.1313 & 37.62 & $5,909,666$ & $6,685,605$ & $\pm 601,704$ \\
\hline St. Joe & -- & СР033 & 20-T29N-R23E & 24.75 & 119,807 & 1.1313 & 32.61 & $1,302,327$ & $1,473,322$ & $\pm 132,599$ \\
\hline St. Joe & Slim Jim & СР037 & 20-T29N-R23E & 3.34 & 16,179 & 1.1313 & 20.47 & 110,403 & 124,899 & $\pm 11,241$ \\
\hline St. Joe & Premier & СР039 & 20-T29N-R23E & 2.96 & 14,319 & 1.1313 & 26.78 & 127,844 & 144,630 & $\pm 13,017$ \\
\hline St. Joe & Vintage (East) & СР038 & 20-T29N-R23E & 3.17 & 15,349 & 1.1313 & 37.06 & 189,625 & 214,522 & $\pm 19,307$ \\
\hline St. Joe & Vintage (West) & СР041 & 20-T29N-R23E & 1.71 & 8,257 & 1.1313 & 17.09 & 47,039 & 53,215 & $\pm 4,789$ \\
\hline St. Joe subtotal & & & & 35.93 & 173,911 & & & $1,777,237$ & $2,010,588$ & $\pm 180,953$ \\
\hline St. Louis No. 6 & -- & ${ }^{3} \mathrm{CP} 200$ & 17-T29N-R23E & 0.93 & 4,512 & 1.1313 & 2.90 & 4,360 & 4,932 & \pm 444 \\
\hline St. Louis No. 6 & -- & ${ }^{3} \mathrm{CP} 201$ & $17-\mathrm{T} 29 \mathrm{~N}-\mathrm{R} 23 \mathrm{E}$ & 0.53 & 2,552 & 1.1313 & 8.02 & 6,818 & 7,713 & \pm 694 \\
\hline St. Louis No. 6 subtotal & & & & 1.46 & 7,063 & & & 11,177 & 12,645 & $\pm 1,138$ \\
\hline Ta Mee Heh & Tam-ah-hah & СР008 & $36-T 29 N-R 22 E$ & 4.70 & 22,746 & 1.1313 & 4.02 & 30,461 & 34,460 & $\pm 3,101$ \\
\hline Western & Anna Beaver & СР029A & 19-T29N-R23E & 43.87 & 212,349 & 1.1313 & 45.25 & $3,202,672$ & $3,623,183$ & $\pm 326,086$ \\
\hline Woodchuck & -- & СР074 & 30-T29N-R23E & 7.30 & 35,323 & 1.1313 & 25.02 & 294,596 & 333,276 & $\pm 29,995$ \\
\hline Woodchuck & -- & СР076 & 30-T29N-R23E & 4.19 & 20,268 & 1.1313 & 21.07 & 142,365 & 161,058 & $\pm 14,495$ \\
\hline Woodchuck & -- & СР075 & $30-\mathrm{T} 29 \mathrm{~N}-\mathrm{R} 23 \mathrm{E}$ & 0.78 & 3,796 & 1.1313 & 12.62 & 15,974 & 18,072 & $\pm 1,626$ \\
\hline Woodchuck subtotal & & & & 12.27 & 59,387 & & & 452,935 & 512,406 & $\pm 46,117$ \\
\hline TOTAL & & & & 383.02 & $1,853,834$ & & & $18,072,538$ & $20,445,462$ & $\pm 1,840,092$ \\
\hline
\end{tabular}


Table 2. Estimates of volume, mass, and change in volume and mass for selected chat piles on properties in the Picher mining district, 0 ttawa County, Oklahoma, 2005 through 2010.-Continued

[BIA, Bureau of Indian Affairs; $\mathrm{yd}^{2}$, square yards; yd $\mathrm{d}^{3}$, cubic yards; ft, feet; --, none; \pm , plus or minus]

\begin{tabular}{|c|c|c|c|c|c|c|c|c|c|}
\hline \multirow{3}{*}{$\begin{array}{l}\text { BIA-approved } \\
\text { property name }\end{array}$} & \multirow{3}{*}{$\begin{array}{l}\text { Chat-pile } \\
\text { identifi- } \\
\text { cation } \\
\text { number }^{1}\end{array}$} & \multirow{2}{*}{\multicolumn{4}{|c|}{ Estimates of volume and mass 2010}} & \multicolumn{4}{|c|}{ Estimates of changes in volume and mass 2005-10 } \\
\hline & & & & & & \multicolumn{2}{|c|}{ Volume } & \multirow{2}{*}{\multicolumn{2}{|c|}{$\begin{array}{l}\text { Mass } \\
\text { (tons) }\end{array}$}} \\
\hline & & $\begin{array}{c}\text { Average } \\
\text { height } \\
\text { (ft) }\end{array}$ & $\begin{array}{l}\text { Volume } \\
\left(\mathrm{yd}^{3}\right)\end{array}$ & & & $\left(y d^{3}\right)$ & (percent) & & \\
\hline Bird Dog & СР004 & 7.74 & 22,495 & 25,449 & $\pm 2,290$ & $-2,524$ & -10.09 & $-2,856$ & $\pm \mathbf{2 5 7}$ \\
\hline Blue Goose & СР072A & 8.67 & 411,073 & 465,047 & $\pm 41,854$ & $-40,777$ & -9.02 & $-46,131$ & $\pm 4,152$ \\
\hline Blue Goose & CP072B & 0.56 & 3,712 & 4,199 & \pm 378 & $-7,438$ & -66.71 & $-8,415$ & \pm 757 \\
\hline Blue Goose & СР079 & 4.02 & 1,252 & 1,417 & \pm 128 & -239 & -16.04 & -271 & \pm 24 \\
\hline Blue Goose & СР080 & 3.42 & 709 & 802 & \pm 72 & -369 & -34.21 & -417 & \pm 38 \\
\hline Blue Goose subtotal & & & 416,746 & 471,465 & $\pm 42,432$ & $-48,823$ & -10.49 & $-55,234$ & $\pm 4,971$ \\
\hline Howe & СР021 & 16.96 & 283,611 & 320,849 & $\pm 28,876$ & $-6,722$ & -2.32 & $-7,605$ & \pm 684 \\
\hline Howe & СР025 & 5.99 & 9,014 & 10,198 & \pm 918 & $-1,564$ & -14.79 & $-1,769$ & \pm 159 \\
\hline Howe subtotal & & & 292,625 & 331,047 & $\pm 29,794$ & $-8,286$ & -2.75 & $-9,374$ & \pm 844 \\
\hline Lawyers & СР061 & 45.80 & $2,118,645$ & $2,396,824$ & $\pm 215,714$ & $-45,877$ & -2.12 & $-51,900$ & $\pm 4,671$ \\
\hline Lucky Bill Humbah & СР077 & 6.79 & 33,165 & 37,519 & $\pm \mathbf{3 , 3 7 7}$ & $-2,582$ & -7.22 & $-2,921$ & \pm 263 \\
\hline OKO & СР036 & 21.76 & 270,918 & 306,490 & $\pm \mathbf{2 7 , 5 8 4}$ & $-10,542$ & -3.75 & $-11,927$ & $\pm \mathbf{1 , 0 7 3}$ \\
\hline Ottawa & $\mathrm{CP} 020$ & 3.89 & 78,222 & 88,492 & $\pm 7,964$ & $-6,504$ & -7.68 & $-7,358$ & \pm 662 \\
\hline Ottawa & ${ }^{2} \mathrm{CP} 022$ & 19.15 & 416,533 & 471,224 & $\pm 42,410$ & $-31,753$ & -7.08 & $-35,923$ & $\pm 3,233$ \\
\hline Ottawa & СР023 & 10.09 & 37,743 & 42,699 & $\pm 3,843$ & $-3,930$ & -9.43 & $-4,446$ & \pm 400 \\
\hline Ottawa & СР024 & 7.49 & 16,671 & 18,860 & $\pm 1,697$ & $-3,941$ & -19.12 & $-4,458$ & \pm 401 \\
\hline Ottawa subtotal & & & 549,169 & 621,275 & $\pm \mathbf{5 5 , 9 1 5}$ & $-46,128$ & -7.75 & $-52,185$ & $\pm 4,697$ \\
\hline Pioneer & CP006A & 17.29 & 400,583 & 453,179 & $\pm 40,786$ & $-16,914$ & -4.05 & $-19,135$ & $\pm 1,722$ \\
\hline Pioneer & СР006B & 20.08 & 183,203 & 207,257 & $\pm 18,653$ & $-6,593$ & -3.47 & $-7,459$ & \pm 671 \\
\hline Pioneer & СР006C & 5.63 & 45,952 & 51,986 & $\pm 4,679$ & $-1,039$ & -2.21 & $-1,175$ & \pm 106 \\
\hline Pioneer & CP006D & 24.39 & 131,045 & 148,252 & $\pm 13,343$ & $-21,258$ & -13.96 & $-24,050$ & $\pm 2,164$ \\
\hline Pioneer & CP006E & 16.07 & 82,198 & 92,991 & $\pm 8,369$ & $-8,292$ & -9.16 & $-9,381$ & \pm 844 \\
\hline Pioneer subtotal & & & 842,981 & 953,664 & $\pm \mathbf{8 5 , 8 3 0}$ & $\mathbf{- 5 4 , 0 9 7}$ & -6.03 & $-61,200$ & $\pm 5,508$ \\
\hline
\end{tabular}


Table 2. Estimates of volume, mass, and change in volume and mass for selected chat piles on properties in the Picher mining district, 0ttawa County, 0klahoma, 2005 through 2010.-Continued

[BIA, Bureau of Indian Affairs; $\mathrm{yd}^{2}$, square yards; $\mathrm{yd}^{3}$, cubic yards; $\mathrm{ft}$, feet; --, none; \pm , plus or minus]

\begin{tabular}{|c|c|c|c|c|c|c|c|c|c|}
\hline \multirow{4}{*}{$\begin{array}{ll}\text { BIA-approved } \\
\text { property name }\end{array}$} & \multirow{4}{*}{$\begin{array}{c}\text { Chat-pile } \\
\text { identifi- } \\
\text { cation } \\
\text { number' }\end{array}$} & \multirow{2}{*}{\multicolumn{4}{|c|}{ Estimates of volume and mass 2010}} & \multicolumn{4}{|c|}{ Estimates of changes in volume and mass 2005-10 } \\
\hline & & & & & & \multirow{3}{*}{$\begin{array}{c}\left(y d^{3}\right) \\
-14,908\end{array}$} & Volume & & \\
\hline & & \multirow{2}{*}{$\begin{array}{c}\begin{array}{c}\text { Average } \\
\text { height } \\
\text { (ft) }\end{array} \\
14.63\end{array}$} & \multirow{2}{*}{$\begin{array}{c}\begin{array}{c}\text { Volume } \\
\left(y d^{3}\right)\end{array} \\
205,803\end{array}$} & \multicolumn{2}{|c|}{$\begin{array}{l}\text { Mass } \\
\text { (tons) }\end{array}$} & & (percent) & \multicolumn{2}{|c|}{$\begin{array}{l}\text { Mass } \\
\text { (tons) }\end{array}$} \\
\hline & & & & 232,824 & $\pm \mathbf{2 0 , 9 5 4}$ & & -6.75 & $-16,866$ & $\pm \mathbf{1 , 5 1 8}$ \\
\hline Skelton & СР066 & 32.59 & $1,637,529$ & $1,852,537$ & $\pm 166,728$ & $-64,545$ & -3.79 & $-73,020$ & $\pm \mathbf{6 , 5 7 2}$ \\
\hline Sooner & ${ }^{2} \mathrm{CP} 013$ & 29.56 & $4,643,474$ & $5,253,163$ & $\pm 472,785$ & $-1,266,191$ & -21.43 & $-1,432,442$ & $\pm 128,920$ \\
\hline St. Joe & CP033 & 29.68 & $1,185,315$ & $1,340,947$ & $\pm 120,685$ & $-117,011$ & -8.98 & $-132,375$ & $\pm 11,914$ \\
\hline St. Joe & $\mathrm{CP} 037$ & 19.54 & 105,400 & 119,239 & $\pm 10,732$ & $-5,003$ & -4.53 & $-5,660$ & \pm 509 \\
\hline St. Joe & СР039 & 24.79 & 118,346 & 133,885 & $\pm 12,050$ & $-9,498$ & -7.43 & $-10,745$ & \pm 967 \\
\hline St. Joe & CP038 & 21.01 & 107,508 & 121,624 & $\pm 10,946$ & $-82,117$ & -43.30 & $-92,899$ & $\pm 8,361$ \\
\hline St. Joe & СР041 & 15.74 & 43,321 & 49,009 & $\pm 4,411$ & $-3,718$ & -7.90 & $-4,206$ & \pm 379 \\
\hline St. Joe subtotal & & & $1,559,890$ & $1,764,704$ & $\pm 158,823$ & $-217,347$ & -12.23 & $-245,884$ & $\pm 22,130$ \\
\hline St. Louis No. 6 & ${ }^{3} \mathrm{CP} 200$ & 2.41 & 3,619 & 4,094 & \pm 368 & -741 & -16.99 & -838 & \pm 75 \\
\hline St. Louis No. 6 & ${ }^{3} \mathrm{CP} 201$ & 6.36 & 5,414 & 6,124 & \pm 551 & $-1,404$ & -20.59 & $-1,588$ & \pm 143 \\
\hline St. Louis No. 6 subtotal & & & 9,033 & 10,219 & \pm 920 & $-2,145$ & -19.19 & $-2,426$ & \pm 218 \\
\hline Ta Mee Heh & СР008 & 3.64 & $\mathbf{2 7 , 5 8 0}$ & 31,201 & $\pm 2,808$ & $-2,881$ & -9.46 & $-3,259$ & $\pm \mathbf{2 9 3}$ \\
\hline Western & CP029A & 44.10 & $3,121,272$ & $3,531,095$ & $\pm 317,799$ & $-81,400$ & -2.54 & $-92,088$ & $\pm \mathbf{8 , 2 8 8}$ \\
\hline Woodchuck & СР074 & 23.17 & 272,851 & 308,677 & $\pm 27,781$ & $-21,745$ & -7.38 & $-24,600$ & $\pm 2,214$ \\
\hline Woodchuck & СР076 & 19.72 & 133,194 & 150,682 & $\pm 13,561$ & $-9,171$ & -6.44 & $-10,376$ & \pm 934 \\
\hline Woodchuck & CP075 & 10.57 & 13,382 & 15,139 & $\pm 1,363$ & $-2,592$ & -16.23 & $-2,933$ & \pm 264 \\
\hline Woodchuck subtotal & & & 419,427 & 474,498 & $\pm 42,705$ & $-33,509$ & -7.40 & $-37,908$ & $\pm 3,412$ \\
\hline TOTAL & & & $16,170,752$ & $18,293,972$ & $\pm 1,646,457$ & $-1,901,786$ & & $-2,151,490$ & $\pm 193,634$ \\
\hline
\end{tabular}


Publishing support provided by Lafayette Publishing Service Center

Information regarding water resources in Oklahoma is available at http://ok.water.usgs.gov/ 


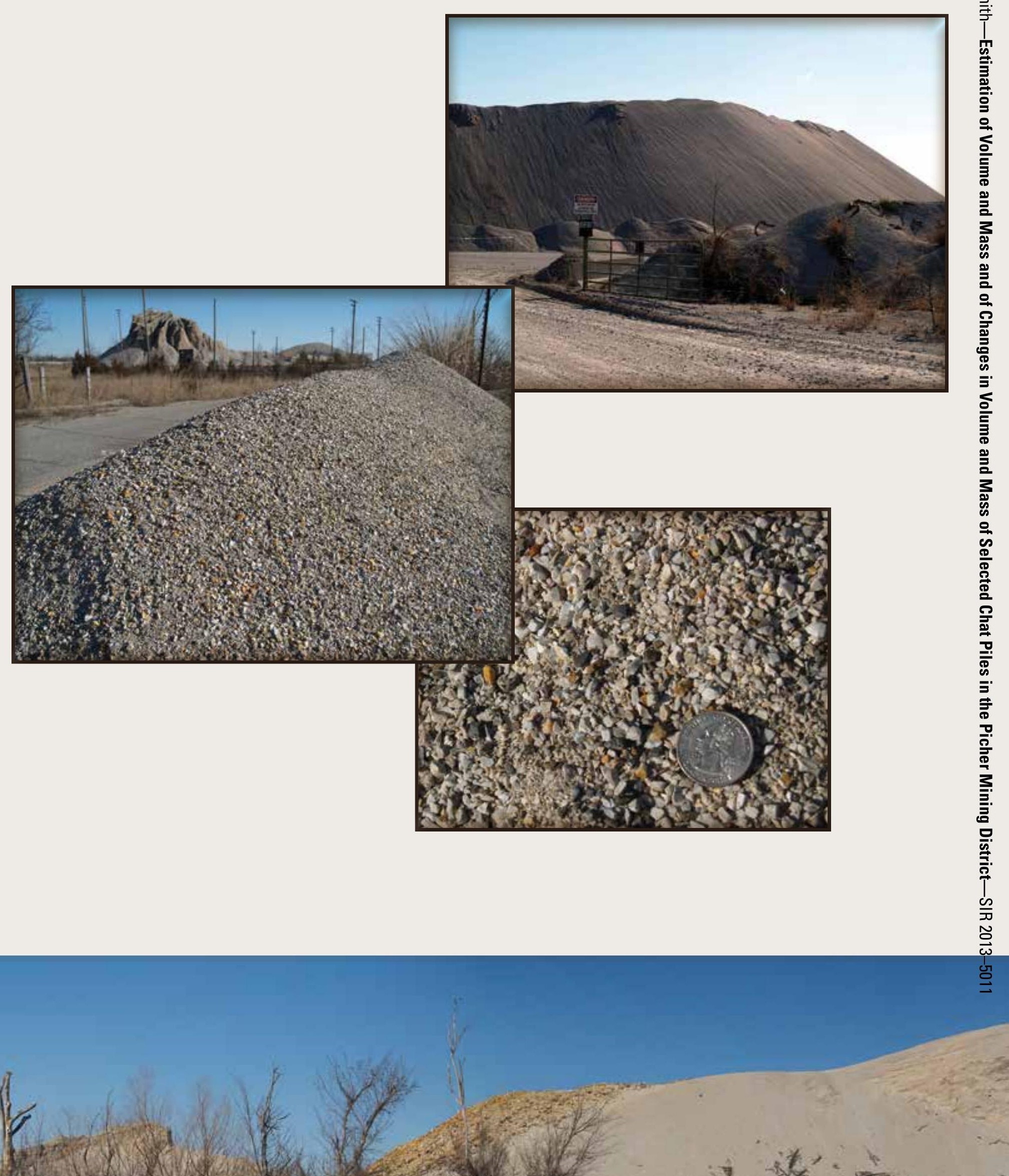

